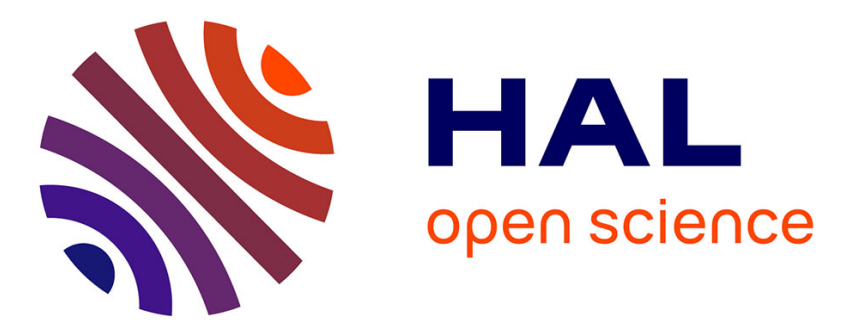

\title{
A new copper(II) coordination polymer containing chains of interconnected paddle-wheel antiferromagnetic clusters
}

\author{
Sofiane Bouheroum, Aouatef Cherouana, Adel Beghidja, Slimane Dahaoui, \\ Pierre Rabu
}

\section{To cite this version:}

Sofiane Bouheroum, Aouatef Cherouana, Adel Beghidja, Slimane Dahaoui, Pierre Rabu. A new copper(II) coordination polymer containing chains of interconnected paddle-wheel antiferromagnetic clusters. Acta Crystallographica Section C: Structural Chemistry [2014-..], 2017, 73 (12), pp.10501055. 10.1107/S2053229617013766 . hal-02342549

\section{HAL Id: hal-02342549 \\ https://hal.science/hal-02342549}

Submitted on 31 Oct 2019

HAL is a multi-disciplinary open access archive for the deposit and dissemination of scientific research documents, whether they are published or not. The documents may come from teaching and research institutions in France or abroad, or from public or private research centers.
L'archive ouverte pluridisciplinaire HAL, est destinée au dépôt et à la diffusion de documents scientifiques de niveau recherche, publiés ou non, émanant des établissements d'enseignement et de recherche français ou étrangers, des laboratoires publics ou privés. 


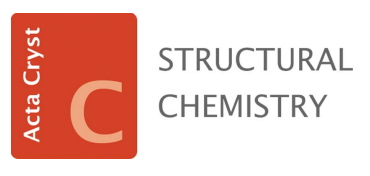

ISSN 2053-2296

Received 24 July 2017

Accepted 25 September 2017

Edited by D. S. Yufit, University of Durham, England

Keywords: one-dimensional coordination polymer; binuclear copper(II) complex; crystal structure; hydrogen bonds; magnetic properties.

CCDC reference: 1515175

Supporting information: this article has supporting information at journals.iucr.org/C

\section{A new copper(II) coordination polymer containing chains of interconnected paddle-wheel anti- ferromagnetic clusters}

\author{
Sofiane Bouheroum, ${ }^{\text {a,b }}$ Aouatef Cherouana, ${ }^{\mathrm{a} *}$ Adel Beghidja, ${ }^{\text {a }}$ Slimane Dahaouic \\ and Pierre Rabu ${ }^{\mathrm{d}}$
}

\begin{abstract}
a Unité de Recherche de Chimie de I'Environnement et Moléculaire Structurale (URCHEMS), Département de Chimie Université, Frères Mentouri de Constantine, 25000 Constantine, Algeria, ${ }^{\mathbf{b} C e n t r e ~ d e ~ D e ́ v e l o p p e m e n t ~ d e s ~ T e c h n o l o g i e s ~}$ Avancées (CDTA), UROP, Sétif 19000, Algeria, 'CRM2 (UMR UL-CNRS 7036) Faculté des Sciences et Technologies, Université de Lorraine, BP 70239 Boulevard des Aiguillettes, 54506 Vandoeuvre-lès-Nancy Cedex, France, and ${ }^{\mathbf{d}}$ Institut de Physique et Chimie des Matériaux de Strasbourg, UMR7504 CNRS-UNISTRA and NIE, 23 rue du Loess, BP 43, 67034 Strasbourg Cedex 2, France. *Correspondence e-mail: c_aouatef@yahoo.fr
\end{abstract}

The construction of supramolecular architectures based on inorganic-organic coordination frameworks with weak noncovalent interactions has implications for the rational design of functional materials. A new crystalline binuclear copper(II) one-dimensional polymeric chain, namely catena-poly[[[tetrakis $(\mu-4-$ azaniumylbutanoato- $\left.\kappa^{2} \mathrm{O}: \mathrm{O}^{\prime}\right) \operatorname{dicopper}(\mathrm{II})(\mathrm{Cu}-\mathrm{Cu})$ ]- $\mu$-chlorido-[diaquadichloridocopper(II)]- $\mu$-chlorido] bis(perchlorate)], $\left\{\left[\mathrm{Cu}_{3} \mathrm{Cl}_{4}\left(\mathrm{C}_{4} \mathrm{H}_{9} \mathrm{NO}_{2}\right)_{4}\left(\mathrm{H}_{2} \mathrm{O}\right)_{2}\right]\right.$ $\left.\left(\mathrm{ClO}_{4}\right)_{2}\right\}_{n}$, was obtained by the reaction of 4-aminobutyric acid (GABA) with $\mathrm{CuCl}_{2} \cdot 2 \mathrm{H}_{2} \mathrm{O}$ in aqueous solution. The structure was established by single-crystal $\mathrm{X}$-ray diffraction and was also characterized by IR spectroscopy and magnetic measurements. The crystal structure consists of $\left[\left\{\mathrm{Cu}_{2}(\mathrm{GABA})_{4}\right\}\left\{\mathrm{CuCl}_{4}-\right.\right.$ $\left.\left.\left(\mathrm{H}_{2} \mathrm{O}\right)_{2}\right\}\right]^{+}$cations and isolated perchlorate anions. Two symmetry-related $\mathrm{Cu}^{\mathrm{II}}$ centres are bridged via carboxylate $\mathrm{O}$ atoms into a classical paddle-wheel configuration, with a $\mathrm{Cu} \cdots \mathrm{Cu}$ distance of 2.643 (1) $\AA$, while bridging $\mathrm{Cl}$ atoms complete the square-pyramidal geometry of the metal atoms. The $\mathrm{Cl}$ atoms connect the paddlewheel moieties to a second $\mathrm{Cu}^{\mathrm{II}}$ atom lying on an octahedral site, resulting in infinite helical chains along the $c$ axis. The packing motif exhibits channels containing free perchlorate anions. The crystal structure is stabilized by hydrogen bonds between the perchlorate anions, the coordinated water molecules and the ammonium groups of the polymeric chains. The magnetic analysis of the title compound indicates a nontrivial antiferromagnetic behaviour arising from alternating weak-strong antiferromagnetic coupling between neighbouring $\mathrm{Cu}^{\mathrm{II}}$ centres.

\section{Introduction}

The investigation of novel metal-organic coordination polymers has attracted a great deal of research interest as a result of their ability to form interesting structures with potential applications in catalysis, molecular adsorption, magnetism, nonlinear optics and electrical conductivity (Mitzi, 1999). In particular, the construction of supramolecular architectures (Moulton \& Zaworotko, 2001) based on inorganic-organic coordination frameworks with weak noncovalent interactions (Steiner, 2002; Desiraju, 2002) is an exciting area of research that has implications for the rational design of functional materials (Evans \& Lin, 2002). The selection of ligands is very important in the construction of these coordination polymers. In this respect, organic carboxylate ligands are widely used to design extended one-, two- or three-dimensional systems with interesting magnetic properties. These ligands show a variety of coordination modes with different metal atoms (Evans \& 
Lin, 2002). Among carboxylate ligands, 4-aminobutyric acid (GABA) is of biological interest because it is a major inhibitory neurotransmitter physiologically active in the central nervous system (Licata et al., 2009; Karakossian et al., 2005). Interestingly, Yogeeswari and co-workers have synthesized new GABA derivatives useful in the treatment of neurological disorders with anticonvulsant and antinociceptive activities (Yogeeswari et al., 2007). There are two crystal forms of GABA, viz. the stable monoclinic phase (Tomita et al., 1973) and the metastable tetragonal phase (Dobson \& Gerkin, 1996). Many derivatives of GABA have been synthesized and reported, such as the potassium salt of GABA (Tokuoka et al., 1981), GABA hydrochloride (Steward et al., 1973) and $\left[\mathrm{CdBr}_{2}(\mathrm{GABA})_{2}\right]$ (Dan \& Rao, 2005). Recently, Fabbiani and co-workers reported the structure of hydrated GABA obtained under high pressure (Fabbiani et al., 2014). We describe, in this article, the synthesis, X-ray crystal structure and magnetic properties of a new coordination polymer based on GABA and copper, namely catena-poly[[tetrakis $(\mu$-4-azaniumylbutanoato)dicopper(II) $(\mathrm{Cu}-\mathrm{Cu})]$ - $\mu$-chlorido-[diaquadichloridocopper(II)]- $\mu$-chlorido] bis(perchlorate)], (I).

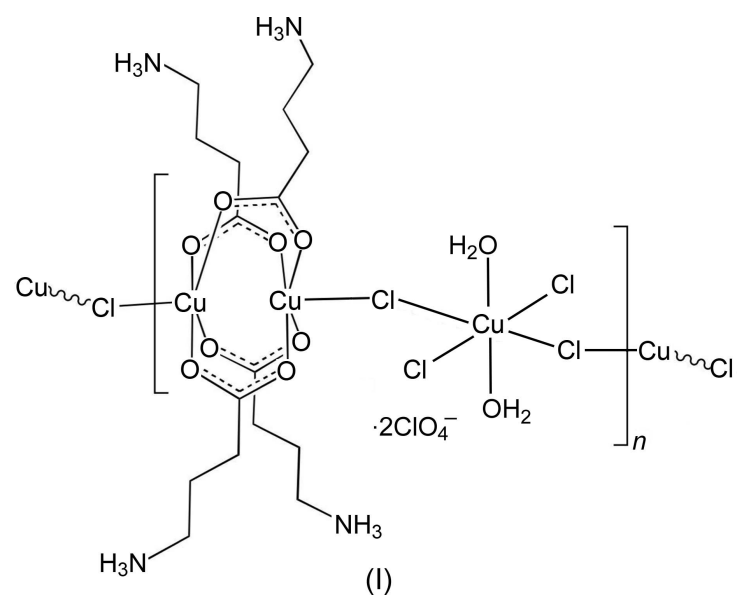

\section{Experimental}

\subsection{Instruments and materials}

2.1.1. Instruments. FT-IR spectra were recorded on an ATI Mattson Genesis in the region $400-4000 \mathrm{~cm}^{-1}$ by transmission through $0.1 \mathrm{~mm}$ thick $\mathrm{KBr}$ pellets containing the powder sample. Magnetic measurements were performed using a Quantum Design SQUID-MPMS magnetometer. Susceptibility was measured on heating in an applied field of $5 \mathrm{kOe}$ and isothermal magnetization was performed at $1.8 \mathrm{~K}$ in a field in the range $\pm 50 \mathrm{kOe}$. Diamagnetic corrections were estimated from Pascal's constants and the sample holder contribution.

2.1.2. Materials. All reagents and solvents for the synthesis and analysis were commercially available, were purchased from Sigma-Aldrich and were used without further purification. All manipulations were performed in air.

\subsection{Synthesis and crystallization}

An aqueous solution $(10 \mathrm{ml})$ of 4-aminobutyric acid $(0.137 \mathrm{~g}, 1 \mathrm{mmol})$ was mixed with an aqueous solution $(15 \mathrm{ml})$
Table 1

Experimental details.

\begin{tabular}{|c|c|}
\hline \multicolumn{2}{|l|}{ Crystal data } \\
\hline Chemical formula & $\begin{array}{l}{\left[\mathrm{Cu}_{3} \mathrm{Cl}_{4}\left(\mathrm{C}_{4} \mathrm{H}_{9} \mathrm{NO}_{2}\right)_{4}\left(\mathrm{H}_{2} \mathrm{O}\right)_{2}\right]-} \\
\quad\left(\mathrm{ClO}_{4}\right)_{2}\end{array}$ \\
\hline$M_{\mathrm{r}}$ & 979.82 \\
\hline Crystal system, space group & Monoclinic, $P 2_{1} / c$ \\
\hline Temperature $(\mathrm{K})$ & 100 \\
\hline$a, b, c(\AA)$ & $12.946(3), 12.568(3), 11.044(2)$ \\
\hline$\beta\left({ }^{\circ}\right)$ & $115.18(3)$ \\
\hline$V\left(\AA^{6}\right)$ & $1626.2(7)$ \\
\hline$Z$ & 2 \\
\hline Radiation type & Мо $K \alpha$ \\
\hline$\mu\left(\mathrm{mm}^{-1}\right)$ & 2.52 \\
\hline Crystal size (mm) & $0.10 \times 0.10 \times 0.08$ \\
\hline \multicolumn{2}{|l|}{ Data collection } \\
\hline Diffractometer & $\begin{array}{l}\text { Oxford Diffraction Supernova } \\
\text { four-circle diffractometer } \\
\text { equipped with an Atlas CCD } \\
\text { detector }\end{array}$ \\
\hline Absorption correction & Integration (DeTitta, 1985) \\
\hline$T_{\min }, T_{\max }$ & $0.720,0.853$ \\
\hline $\begin{array}{l}\text { No. of measured, independent and } \\
\text { observed }[I>2 \sigma(I)] \text { reflections }\end{array}$ & $19050,3805^{*}, 15048$ \\
\hline$R_{\text {int }}$ & 0.038 \\
\hline$(\sin \theta / \lambda)_{\max }\left(\AA^{-1}\right)$ & 0.654 \\
\hline \multicolumn{2}{|l|}{ Refinement } \\
\hline$R\left[F^{2}>2 \sigma\left(F^{2}\right)\right], w R\left(F^{2}\right), S$ & $0.044,0.109,0.99$ \\
\hline No. of reflections & 19050 \\
\hline No. of parameters & 217 \\
\hline No. of restraints & 3 \\
\hline H-atom treatment & H-atom parameters constrained \\
\hline$\Delta \rho_{\max }, \Delta \rho_{\min }\left(\mathrm{e} \AA^{-3}\right)$ & $1.26,-1.92$ \\
\hline
\end{tabular}

Computer programs: CrysAlis PRO (Oxford Diffraction, 2008), SIR97 (Altomare et al., 1999), SHELXL2014 (Sheldrick, 2015), DIAMOND (Brandenburg, 2012) and OLEX2 (Dolomanov et al, 2009). Note: (*) Because twin refinement was used, the input data were not merged for the least-squares calculations.

of $\mathrm{CuCl}_{2} \cdot 2 \mathrm{H}_{2} \mathrm{O}(0.170 \mathrm{~g}, 1 \mathrm{mmol})$ at room temperature with constant stirring and gentle heating for $1 \mathrm{~h}$. An aqueous solution of lithium perchlorate $(0.106 \mathrm{~g}, 1 \mathrm{mmol})$ was added dropwise and the final mixture was kept at room temperature. After several weeks, green crystals appeared, from which crystals suitable for X-ray analysis were chosen. CAUTION! Perchlorate salts are potentially dangerous and should be handled with appropriate care.

\subsection{Refinement}

Crystal data, data collection and structure refinement details are summarized in Table 1. All $\mathrm{H}$ atoms (ligand and water) were located in difference electron-density maps and treated as riding on their parent atoms, with $\mathrm{C}-\mathrm{H}=0.99 \AA, \mathrm{N}-\mathrm{H}=$ $0.91 \AA$ and $\mathrm{O}-\mathrm{H}=1.00 \AA$, and with $U_{\text {iso }}(\mathrm{H})=1.2 U_{\text {eq }}(\mathrm{C}, \mathrm{N}, \mathrm{O})$. The sample crystal was twinned, with major and minor twin components of 0.5507 (19) and 0.4493 (19), respectively. As a consequence, a twin refinement by means of the SHELXL HKLF 5 instruction (Sheldrick, 2015) was employed.

\section{Results and discussion}

\subsection{Crystal structure}

The crystal structure of the title compound consists of cationic polymeric chains, built on an alternating sequence of 


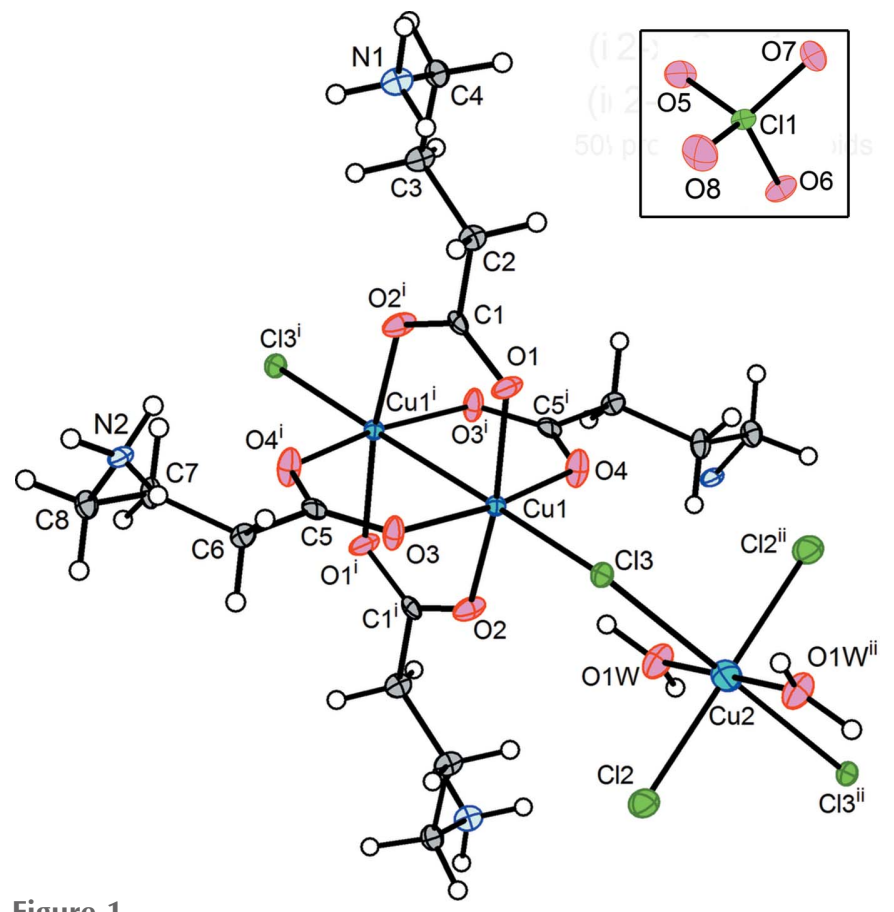

Figure 1

Displacement ellipsoid plot (50\% probability level) of (I). The inset shows the perchlorate anion, but the orientation is not the same as that of the main fragment. [Symmetry codes: (i) $-x+2,-y+2,-z+1$; (ii) $-x+2,-y+2,-z$.

dimeric $\left[\mathrm{Cu}_{2} \mathrm{Cl}_{2} \mathrm{O}_{8}\right]$ copper(II) entities and octahedral $\left[\mathrm{CuCl}_{4}\left(\mathrm{H}_{2} \mathrm{O}\right)_{2}\right]$ groups, the two entities sharing $\mathrm{Cl}$ atoms. Perchlorate anions balance the charge of the copper framework, functionalized with ammonium-carboxylate groups (Fig. 1). Selected bond lengths and angles are listed in Table 2. The dimeric unit exists as a divalent cation with the two $\mathrm{Cu}^{\text {II }}$ atoms bridged by the carboxylate groups of four GABA ligands. The GABA ligand is in its zwitterionic form (4-azaniumylbutanoate) and is thus neutral. Atom $\mathrm{Cu} 1$ adopts a square-pyramidal geometry, with four carboxylate $\mathrm{O}$ atoms in

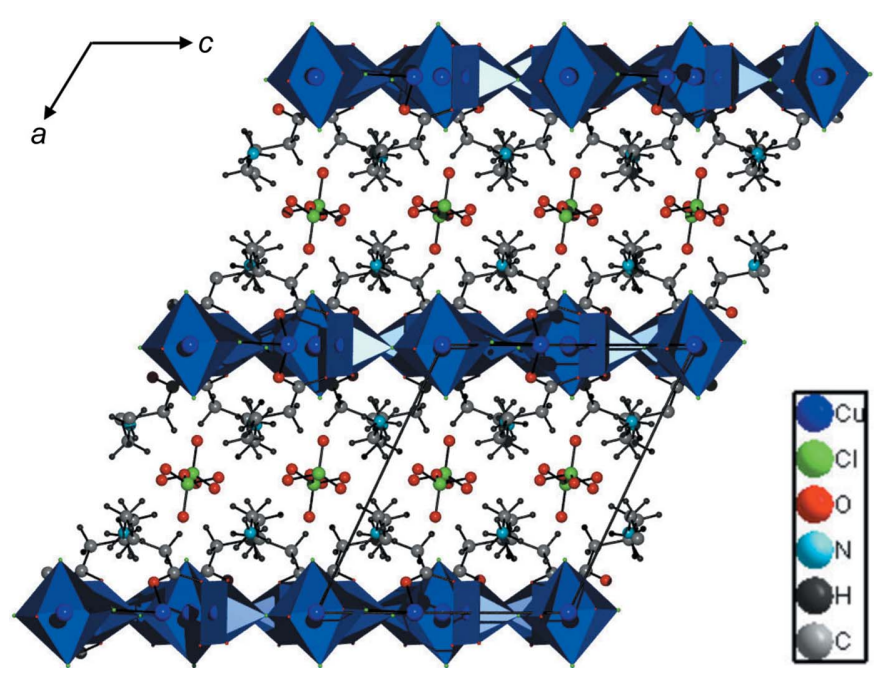

Figure 2

View along $b$ of the structure of (I), showing the polyhedra around the $\mathrm{Cu}^{\mathrm{II}}$ atoms and the perchlorate anions in the inter-chain channels.
Table 2

Selected geometric parameters $\left(\AA,{ }^{\circ}\right)$.

\begin{tabular}{lcll}
\hline $\mathrm{Cu} 1-\mathrm{Cl} 3$ & $2.4312(18)$ & $\mathrm{Cu} 2-\mathrm{O} 1 W$ & $2.030(5)$ \\
$\mathrm{Cu} 1-\mathrm{O} 1$ & $1.966(5)$ & $\mathrm{O} 1-\mathrm{C} 1$ & $1.260(9)$ \\
$\mathrm{Cu} 1-\mathrm{O} 2$ & $1.977(6)$ & $\mathrm{O} 2-\mathrm{C} 1^{\mathrm{i}}$ & $1.256(10)$ \\
$\mathrm{Cu} 1-\mathrm{O} 3$ & $1.975(6)$ & $\mathrm{O} 3-\mathrm{C} 5$ & $1.256(9)$ \\
$\mathrm{Cu} 1-\mathrm{O} 4$ & $1.974(6)$ & $\mathrm{O} 4-\mathrm{C} 5^{\mathrm{i}}$ & $1.265(9)$ \\
$\mathrm{Cu} 2-\mathrm{Cl} 2$ & $2.331(2)$ & $\mathrm{N} 1-\mathrm{C} 4$ & $1.502(9)$ \\
$\mathrm{Cu} 2-\mathrm{Cl} 3$ & $2.7554(17)$ & $\mathrm{N} 2-\mathrm{C} 8$ & $1.487(9)$ \\
& & & \\
$\mathrm{Cl} 3-\mathrm{Cu} 1-\mathrm{O} 1$ & $93.59(16)$ & $\mathrm{Cl} 3-\mathrm{Cu} 2-\mathrm{O} 1 W^{\mathrm{ii}}$ & $88.83(15)$ \\
$\mathrm{Cl} 3-\mathrm{Cu} 1-\mathrm{O} 2$ & $98.67(16)$ & $\mathrm{Cu} 1-\mathrm{Cl}-\mathrm{Cu} 2$ & $113.22(6)$ \\
$\mathrm{Cl} 3-\mathrm{Cu} 1-\mathrm{O} 3$ & $92.31(16)$ & $\mathrm{Cu} 1-\mathrm{O} 1-\mathrm{C} 1$ & $124.4(5)$ \\
$\mathrm{Cl} 3-\mathrm{Cu} 1-\mathrm{O} 4$ & $99.40(17)$ & $\mathrm{Cu} 1-\mathrm{O} 2-\mathrm{C} 1^{\mathrm{i}}$ & $122.7(5)$ \\
$\mathrm{O} 1-\mathrm{Cu} 1-\mathrm{O} 2$ & $167.7(2)$ & $\mathrm{Cu} 1-\mathrm{O} 3-\mathrm{C} 5$ & $125.7(5)$ \\
$\mathrm{O} 1-\mathrm{Cu} 1-\mathrm{O} 3$ & $90.3(2)$ & $\mathrm{Cu} 1-\mathrm{O} 4-\mathrm{C} 5^{\mathrm{i}}$ & $120.6(6)$ \\
$\mathrm{O} 1-\mathrm{Cu} 1-\mathrm{O} 4$ & $88.6(2)$ & $\mathrm{O} 2{ }^{\mathrm{i}}-\mathrm{C} 1-\mathrm{C} 2$ & $119.9(6)$ \\
$\mathrm{O} 2-\mathrm{Cu} 1-\mathrm{O} 3$ & $90.5(2)$ & $\mathrm{O} 1-\mathrm{C} 1-\mathrm{C} 2$ & $115.3(7)$ \\
$\mathrm{O} 2-\mathrm{Cu} 1-\mathrm{O} 4$ & $88.2(2)$ & $\mathrm{O} 1-\mathrm{C} 1-\mathrm{O} 2^{\mathrm{i}}$ & $124.8(7)$ \\
$\mathrm{O} 3-\mathrm{Cu} 1-\mathrm{O} 4$ & $168.3(2)$ & $\mathrm{N} 1-\mathrm{C} 4-\mathrm{C} 3$ & $110.5(7)$ \\
$\mathrm{Cl} 2-\mathrm{Cu} 2-\mathrm{Cl} 3$ & $89.13(7)$ & $\mathrm{O} 3-\mathrm{C} 5-\mathrm{O} 4^{\mathrm{i}}$ & $125.3(7)$ \\
$\mathrm{Cl} 2-\mathrm{Cu} 2-\mathrm{O} 1 W$ & $89.49(19)$ & $\mathrm{O} 3-\mathrm{C} 5-\mathrm{C} 6$ & $116.8(6)$ \\
$\mathrm{Cl} 2-\mathrm{Cu} 2-\mathrm{Cl} 3^{\mathrm{ii}}$ & $90.87(7)$ & $\mathrm{O} 4{ }^{\mathrm{i}}-\mathrm{C} 5-\mathrm{C} 6$ & $117.9(7)$ \\
$\mathrm{Cl} 2-\mathrm{Cu} 2-\mathrm{O} 1 W^{\mathrm{ii}}$ & $90.51(19)$ & $\mathrm{N} 2-\mathrm{C} 8-\mathrm{C} 7$ & $111.8(7)$ \\
$\mathrm{Cl} 3-\mathrm{Cu} 2-\mathrm{O} 1 W$ & $91.17(15)$ & & \\
\hline
\end{tabular}

Symmetry codes: (i) $-x+2,-y+2,-z+1$; (ii) $-x+2,-y+2,-z$.

the basal plane and a $\mathrm{Cl} 3$ atom in the apical site, and is slightly displaced from the basal plane by 0.206 (1) $\AA$. The $\mathrm{Cl}-$ $\mathrm{Cu} \cdot \mathrm{Cu}^{\mathrm{i}}$ angle of $173.56(1)^{\circ}$ [symmetry code: (i) $-x+2$, $-y+2,-z+1]$ indicates that the $\mathrm{Cl}-\mathrm{Cu} \cdots \mathrm{Cu}^{\mathrm{i}}$ moiety is not strictly linear, similar to other compounds with a similar dimeric copper core (Jezierska et al., 1998; Chen et al., 1998). Atom $\mathrm{Cu} 2$ is located on an inversion centre and exhibits a distorted octahedral geometry whose base is formed by two $\mathrm{Cl}$ atoms and two coordinated water molecules. The apical positions are occupied by a bridging $\mathrm{Cl} 2$ atom shared with the square pyramid of $\mathrm{Cu} 1$, giving an alternating succession of square-pyramidal and octahedral $\mathrm{Cu}^{\text {II }}$ ions along the $c$ axis (Fig. 2). The distortion of the $\mathrm{Cu} 2$ geometry is due to an elongation of the two axial bonds resulting from the JahnTeller effect. The crystal structure of (I) involves an extensive hydrogen-bond network. These hydrogen bonds occur within and between the chains, as well as between the polymeric chains and perchlorate anions (Table 3). The coordinated water molecules act as hydrogen-bond donors for symmetry-

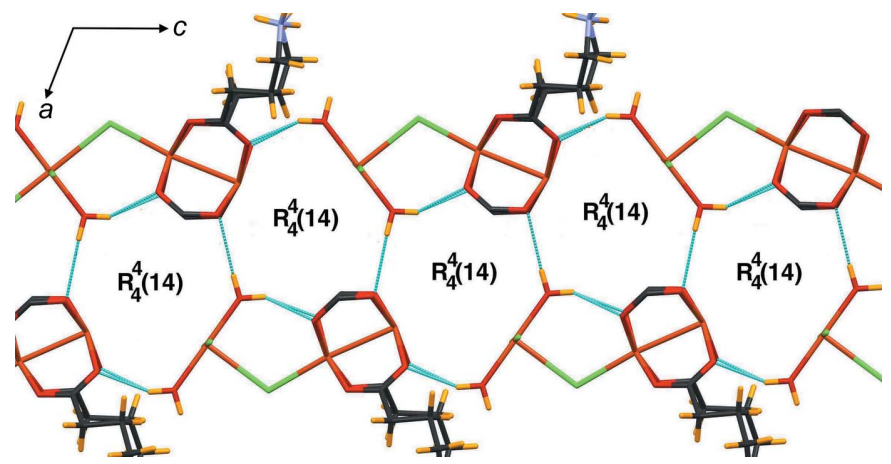

Figure 3

The hydrogen-bond scheme involving the water molecules. Ligand atoms have been omitted for clarity. 
Table 3

Hydrogen-bond geometry $\left(\AA,^{\circ}\right)$.

\begin{tabular}{|c|c|c|c|c|}
\hline$D-\mathrm{H} \cdots A$ & $D-\mathrm{H}$ & $\mathrm{H} \cdots A$ & $D \cdots A$ & $D-\mathrm{H} \cdots A$ \\
\hline $\mathrm{O} 1 W-\mathrm{H} 1 W A \cdots \mathrm{O} 2$ & 1.0000 & 2.2500 & $3.046(9)$ & 135.00 \\
\hline $\mathrm{O} 1 W-\mathrm{H} 1 W A \cdots \mathrm{O} 4$ & 1.0000 & 2.5000 & $3.234(7)$ & 130.00 \\
\hline $\mathrm{N} 1-\mathrm{H} 1 A \cdots \mathrm{Cl} 2^{\mathrm{iii}}$ & 0.9100 & 2.3200 & $3.214(6)$ & 166.00 \\
\hline $\mathrm{N} 1-\mathrm{H} 1 B \cdots \mathrm{O} 1^{\mathrm{iv}}$ & 0.9100 & 2.1800 & $3.075(9)$ & 169.00 \\
\hline $\mathrm{N} 1-\mathrm{H} 1 B \cdots \mathrm{O} 4^{\mathrm{iv}}$ & 0.9100 & 2.4500 & $2.989(9)$ & 118.00 \\
\hline $\mathrm{N} 1-\mathrm{H} 1 C \cdots \mathrm{O}^{\mathrm{v}}$ & 0.9100 & 2.5900 & $3.015(9)$ & 109.00 \\
\hline $\mathrm{N} 1-\mathrm{H} 1 C \cdots \mathrm{O}^{\mathrm{vi}}$ & 0.9100 & 2.2600 & $3.074(8)$ & 148.00 \\
\hline $\mathrm{O} 1 W-\mathrm{H} 1 W B \cdots \mathrm{O} 1^{\mathrm{vii}}$ & 0.9900 & 2.3500 & $3.252(7)$ & 151.00 \\
\hline $\mathrm{N} 2-\mathrm{H} 2 A \cdots \mathrm{O} 6^{\text {viii }}$ & 0.9100 & 2.5000 & $3.146(8)$ & 128.00 \\
\hline $\mathrm{N} 2-\mathrm{H} 2 A \cdots \mathrm{Cl} 2^{\mathrm{iv}}$ & 0.9100 & 2.4900 & $3.245(6)$ & 140.00 \\
\hline $\mathrm{N} 2-\mathrm{H} 2 B \cdots \mathrm{O} 7$ & 0.9100 & 2.1100 & $2.956(8)$ & 154.00 \\
\hline $\mathrm{N} 2-\mathrm{H} 2 C \cdots \mathrm{Cl}^{3}{ }^{\mathrm{iv}}$ & 0.9100 & 2.4600 & $3.316(7)$ & 157.00 \\
\hline $\mathrm{N} 2-\mathrm{H} 2 C \cdots \mathrm{O} 3^{\text {iv }}$ & 0.9100 & 2.5000 & $3.075(7)$ & 122.00 \\
\hline $\mathrm{C} 2-\mathrm{H} 2 D \cdots \mathrm{Cl} 2^{\mathrm{iii}}$ & 0.9900 & 2.8200 & $3.708(7)$ & 149.00 \\
\hline $\mathrm{C} 2-\mathrm{H} 2 D \cdots \mathrm{Cl} 3^{\mathrm{iv}}$ & 0.9900 & 2.8000 & $3.511(8)$ & 129.00 \\
\hline $\mathrm{C} 4-\mathrm{H} 4 A \cdots \mathrm{O}^{\mathrm{v}}$ & 0.9900 & 2.5800 & $3.215(9)$ & 122.00 \\
\hline $\mathrm{C} 6-\mathrm{H} 6 A \cdots \mathrm{N} 2$ & 0.9900 & 2.6100 & $3.031(9)$ & 106.00 \\
\hline $\mathrm{C} 8-\mathrm{H} 8 B \cdots \mathrm{O} 8^{\text {viii }}$ & 0.9900 & 2.5100 & $3.294(9)$ & 136.00 \\
\hline
\end{tabular}

Symmetry codes: (iii) $-x+2, y-\frac{1}{2},-z+\frac{1}{2}$; (iv) $x,-y+\frac{3}{2}, z+\frac{1}{2}$; (v) $x+1, y$, $z$; (vi) $-x+2,-y+1,-z+2$; (vii) $-x+2, y+\frac{1}{2},-z+\frac{1}{2}$; (viii) $-x+1,-y+1,-z+1$.

related chelated carboxylate $\mathrm{O}$ atoms $(\mathrm{O} 1, \mathrm{O} 2$ and $\mathrm{O} 4)$. Atom $\mathrm{H} 1 W A$ forms two intra-polymer hydrogen bonds with atoms $\mathrm{O} 2$ and $\mathrm{O} 4$, thus reinforcing these polymeric chains, while atom $\mathrm{H} 1 W B$ provides the connection between two different chains via an $\mathrm{H} 1 W B \cdots \mathrm{O} 1^{\text {vii }}$ interaction. The combination of these three hydrogen bonds results in rings with the motif $R_{4}^{4}(14)$ (Etter, 1990; Bernstein et al., 1995), which repeats along the $c$ axis, giving rise to a ribbon structure with the graph-set descriptor $C\left[R_{4}^{4}(14)\right]$ (Fig. 3). Perchlorate anions are

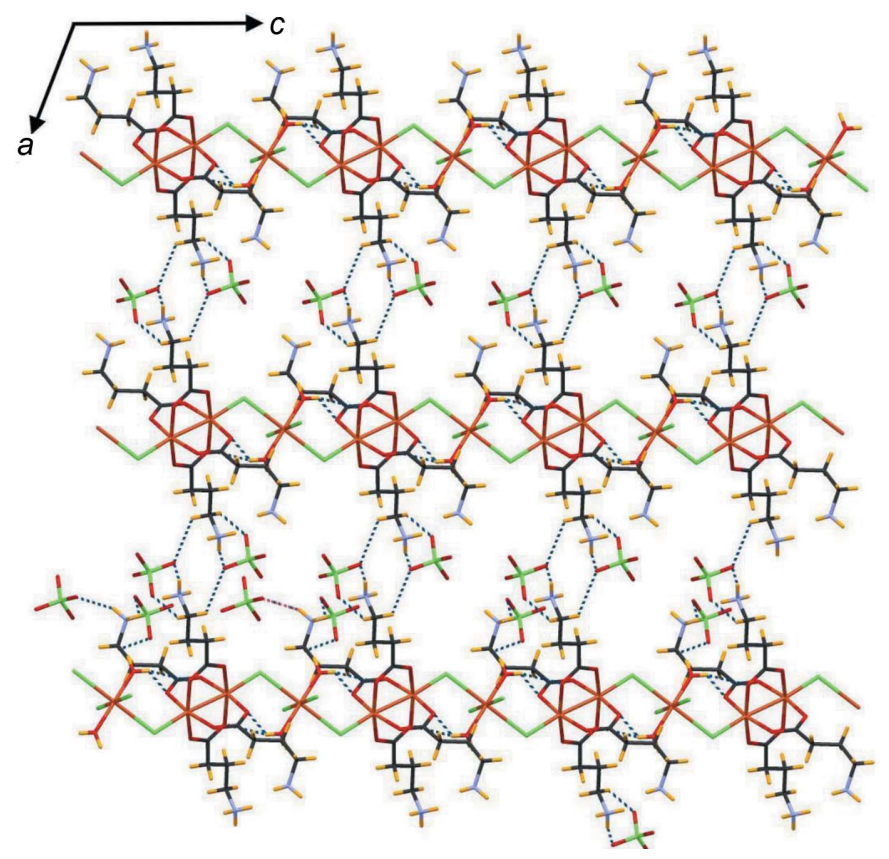

Figure 4

A view of the three-dimensional network of the title compound formed via $\mathrm{N}-\mathrm{H} \cdots \mathrm{O}$ and $\mathrm{C}-\mathrm{H} \cdots \mathrm{O}$ hydrogen bonds between GABA ligands and perchlorate anions, showing the alternation of the cationic and anionic layers.

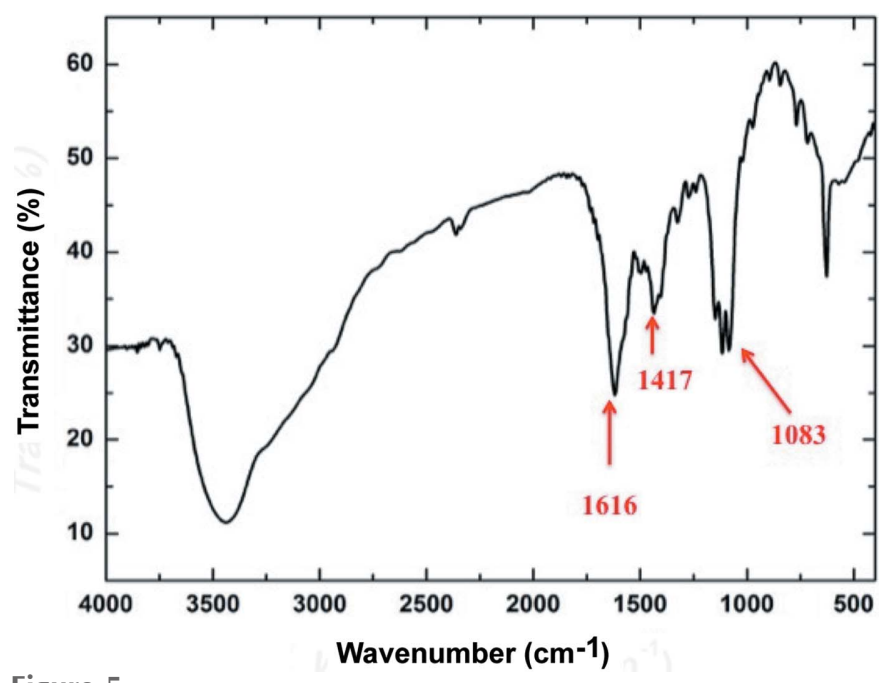

Figure 5

The FT-IR spectrum of (I).

sandwiched between these polymeric ribbons, generating an alternating succession of cationic layers and perchlorate layers (Fig. 4). These units are linked by $\mathrm{N}-\mathrm{H} \cdots \mathrm{O}$ and $\mathrm{C}-\mathrm{H} \cdots \mathrm{O}$ hydrogen bonds involving the GABA ligand, thus forming a three-dimensional hydrogen-bond network. All hydrogen bonds have significant strength and should thus participate in the global stabilization of the structure.

\subsection{FT-IR spectroscopic study}

The IR spectrum of the title compound (Fig. 5) shows broad stretching bands in the $3100-3500 \mathrm{~cm}^{-1}$ range, assignable to the antisymmetrical and symmetrical $\mathrm{H}-\mathrm{O}-\mathrm{H}$ stretching vibrations (Chen et al., 1998) of water molecules. These bands overlap other stretching bands resulting from $\mathrm{N}-\mathrm{H} \cdots \mathrm{O}$ and $\mathrm{O} W-\mathrm{H} \cdots \mathrm{O}$ moieties. The band at $1083 \mathrm{~cm}^{-1}$ corresponds to uncoordinated perchlorate ions (Chaplin, 2016; Deacon \& Phillips, 1980). The FT-IR spectrum also exhibits two strong bands at 1616 and $1417 \mathrm{~cm}^{-1}$ which are assigned to the antisymmetrical and symmetrical stretching vibrations of the carboxylate groups of the ligand, respectively. The difference

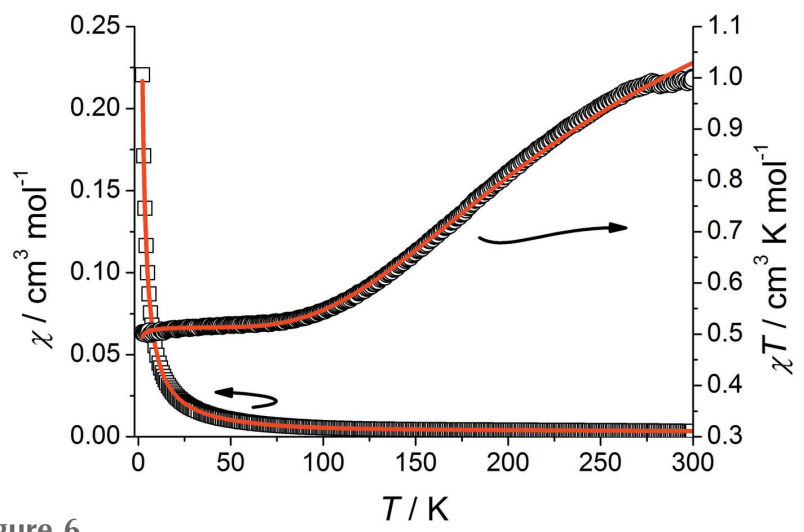

Figure 6

$\chi$ (black squares) and $\chi T$ (black circles) as a function of temperature measured in a field of 5000 Oe for (I). The red solid lines correspond to the best fit of the data (see text). 
of $199 \mathrm{~cm}^{-1}$ between the antisymmetrical and symmetrical stretching vibrations is in agreement with the syn-syn bidentate bridging $\mu_{2}, \kappa^{2} O: O^{\prime}$-mode of the carboxylate groups (Schechter et al., 1995; Zeleňák et al., 2004). Bands between 1000 and $1250 \mathrm{~cm}^{-1}$ are attributed to $\mathrm{C}-\mathrm{C}$ and $\mathrm{C}-\mathrm{N}$ stretching vibration bands of the GABA ligand (Zeleňák et al., 2007).

\subsection{Magnetic properties}

The magnetic properties of (I) were studied on randomly oriented polycrystalline samples. The magnetic susceptibility is plotted as $\chi T$ and $\chi$ versus $T$ curves in (Fig. 6). The magnetic susceptibility increases continuously from room temperature to $2 \mathrm{~K}$. The $\chi T(T)$ product decreases steeply from $1.04 \mathrm{~cm}^{3} \mathrm{~K} \mathrm{~mol}^{-1}$ at $300 \mathrm{~K}$, reaching a plateau at $c a$ $0.50 \mathrm{~cm}^{3} \mathrm{~K} \mathrm{~mol}^{-1}$ below $100 \mathrm{~K}$. The high temperature value is below that expected for three $\mathrm{Cu}^{2+}$ ions $\left(0.4-0.5 \mathrm{~cm}^{3} \mathrm{~K}\right.$ per $\mathrm{Cu}$ mol). The plateau below $100 \mathrm{~K}$ agrees quite well with the contribution of one $\mathrm{Cu}^{\mathrm{II}}$ atom. Accordingly, the magnetization versus field curve shown in Fig. 7 suggests a paramagnetic-like behaviour at $1.8 \mathrm{~K}$. However, the saturation value of $0.55 \mu_{\mathrm{B}} /$ $\mathrm{Cu}^{2+}$ ion at $H=5 \mathrm{~T}$ is almost half of that expected for one $S=\frac{1}{2}$ spin. Hence, the magnetic behaviour of (I) does not simply consist of the superposition of antiferromagnetic dimers and isolated paramagnetic centres. Rather, it suggests the presence of strong antiferromagnetic coupling all along the chains. Actually, based on the structure, one can consider two interactions, namely $J_{1}$ between adjacent $\mathrm{Cu} 1$ and $\mathrm{Cu} 2$ atoms, and $J_{2}$ within the $\mathrm{Cu} 1 \cdots \mathrm{Cu} 1 \mathrm{dimeric}$ units. To evaluate these exchange interaction values, the experimental data were fitted using a numerical approach to solve the Hamiltonian corresponding to the present chain structure:

$$
\begin{aligned}
\hat{H}= & -\sum_{i=1}^{\frac{N}{4}}\left[J_{1}\left(\hat{S}_{3 i} \hat{S}_{3 i+1}+\hat{S}_{3 i} \hat{S}_{3 i-1}\right)+J_{2} \hat{S}_{3 i+1} \cdot \hat{S}_{3 i+2}\right] \\
& -g \mu_{\mathrm{B}} \sum_{i=1}^{N} \hat{S} . \vec{H} .
\end{aligned}
$$

In this expression, the first term holds for the exchange coupling along $\{\mathrm{Cu} 1 \cdots \mathrm{Cu} 2 \cdots \mathrm{Cu} 1 \cdots \mathrm{Cu} 1\}_{n}$ chains. The Landé factor $g$ was kept identical for all spin centres. The actual model for a chain should involve an infinity of spin centres. Due to computation limitations, the number of spins were limited. To avoid a symmetry breaking artefact for finite linear chains, the data were fitted by iterative diagonalization of the exchange interaction matrix written on the basis of the above Hamiltonian for rings of $12 S=\frac{1}{2}$ spins (SPIN; Legoll et al., 2017). [SPIN is code for the calculation and fitting of the magnetic properties of low-dimensional systems. The code encompasses one diagonalization subroutine from the library of IDRIS (Orsay, France). The minimization program MINUIT from the CERN library (CERN, Geneva, Switzerland) is included for fitting the experimental curves.] The result of the numerical approach is shown in Fig. 7. A good agreement was obtained for $J_{1} / k=-12.5(2) \mathrm{K}, J_{2} / k=$ -473 (2) $\mathrm{K}$ and $g=2.28$ (1). The $g$ value, which is a mean

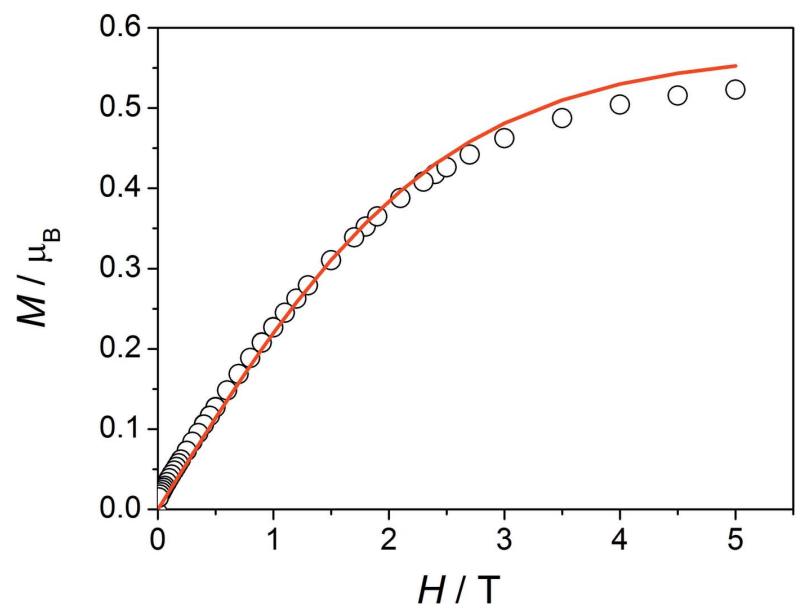

Figure 7

Isothermal magnetization of (I) recorded at $1.8 \mathrm{~K}$. The full line corresponds to the direct calculation of $M(H)$ with the values of $J_{1}, J_{2}$ and $g$ obtained by fitting the susceptibility data.

value for the two $\mathrm{Cu}^{\mathrm{II}}$ sites, is within the range reported in the literature (Carlin, 1986). The very strong value of $J_{2}$ is in agreement with that observed in similar paddlewheel dimers (Kahn, 1993; Carlin, 1986). Thus, the behaviour of the chains appears dominated by that of the strongly antiferromagnetic $\mathrm{Cu} 1 \cdots \mathrm{Cu} 1$ dimers. However, the paramagnetic $\mathrm{Cu} 2$ centres are not innocent, as they act as a relay between the paddlewheel units, transmitting significant antiferromagnetic interactions along the chains. Using the same numerical procedure as above, we have calculated the magnetization versus field variation with the fitted values of $J_{1}, J_{2}$ and $g$. A pretty good agreement was obtained when compared with the experimental data, as shown in Fig. 7, which confirms the significance of the values obtained.

\section{Acknowledgements}

The authors acknowledge CRM2, Institut Jean Barriol (UMR 7036 CNRS, University de Lorraine, France), for providing access to crystallographic experimental facilities.

\section{References}

Altomare, A., Burla, M. C., Camalli, M., Cascarano, G. L., Giacovazzo, C., Guagliardi, A., Moliterni, A. G. G., Polidori, G. \& Spagna, R. (1999). J. Appl. Cryst. 32, 115-119.

Bernstein, J., Davis, R. E., Shimoni, L. \& Chang, N. L. (1995). Angew. Chem. Int. Ed. Engl. 34, 1555-1573.

Brandenburg, K. (2012). DIAMOND. Crystal Impact GbR, Bonn, Germany.

Carlin, R. L. (1986). In Magnetochemistry. Berlin: Springer-Verlag.

Chaplin, M. (2016). Water Absoption Spectrum. Available online: http://www1.lsbu.ac.uk/water/water_vibrational_spectrum.html. (Accessed 12 May 2016.)

Chen, X.-M., Feng, X.-L., Xu, Z.-T., Zhang, X.-H. \& Mak, T. C. W. (1998). Polyhedron, 17, 2639-2646.

Dan, M. \& Rao, C. N. R. (2005). Chem. Eur. J. 11, 7102-7109.

Deacon, G. B. \& Phillips, R. J. (1980). Coord. Chem. Rev. 33, $227-$ 250.

Desiraju, G. R. (2002). Acc. Chem. Res. 35, 565-573.

DeTitta, G. T. (1985). J. Appl. Cryst. 18, 75-79. 
Dobson, A. J. \& Gerkin, R. E. (1996). Acta Cryst. C52, 3075-3078.

Dolomanov, O. V., Bourhis, L. J., Gildea, R. J., Howard, J. A. K. \& Puschmann, H. (2009). J. Appl. Cryst. 42, 339-341.

Etter, M. C. (1990). Acc. Chem. Res. 23, 120-126.

Evans, O. R. \& Lin, W. (2002). Acc. Chem. Res. 35, 511-522.

Fabbiani, F. B. A., Buth, G., Levendisc, D. C. \& Cruz-Cabeza, A. J. (2014). Chem. Commun. 50, 1817-1819.

Jezierska, J., Glowiak, T., Ozarowski, A., Yablokov, Yu. V. \& Rzaczynska, Z. (1998). Inorg. Chim. Acta, 28-36, 275-276.

Kahn, O. (1993). In Molecular Magnetism. Weinheim: VCH.

Karakossian, S. R., Spencer, A. Q., Gomez, O. R., Padilla, A., Sacher, D. D. F., Loo, N., Nelson, S. \& Eskandari, S. (2005). J. Membr. Biol. 203, 65-82.

Legoll, P., Drillon, M., Rabu, P. \& Maingot, F. (2017). SPIN. Version 2.35. CNRS, Orsay, France, and CERN, Geneva, Switzerland.

Licata, S. C., Platt, D. M., Cook, J. M., Van Linn, M. L. \& Rowlett, J. K. (2009). Psychopharmacology (Berlin), 203, 539-546.

Mitzi, D. B. (1999). Prog. Inorg. Chem. 48, 1-121.

Moulton, B. \& Zaworotko, M. J. (2001). Chem. Rev. 101, 1629-1658.
Oxford Diffraction (2008). CrysAlis CCD and CrysAlis RED. Oxford Diffraction, Wrocław, Poland.

Schechter, B., Arnon, R. \& Wilchek, M. (1995). React. Polym. 25, 167-175.

Sheldrick, G. M. (2015). Acta Cryst. C71, 3-8.

Steiner, T. (2002). Angew. Chem. Int. Ed. 41, 48-76.

Steward, E. G., Player, R. B. \& Warner, D. (1973). Acta Cryst. B29, 2825-2826.

Tokuoka, R., Abe, M., Matsumoto, K., Shirakawa, K., Fujiwara, T. \& Tomita, K.-I. (1981). Acta Cryst. B37, 445-447.

Tomita, K., Higashi, H. \& Fujiwara, T. (1973). Bull. Chem. Soc. Jpn, 46, 2199-2204.

Yogeeswari, P., Ragavendran, J. V., Sriram, D., Nageswari, Y., Kavya, R., Sreevatsan, N., Vanitha, K. \& Stables, J. (2007). J. Med. Chem. 50, 2459-2467.

Zeleňák, V., Sabo, M., Massa, W. \& Černák, J. (2004). Acta Cryst. C60, m85-m87.

Zeleňák, V., Vargova, Z. \& Gyoryova, K. (2007). Spectrochim. Acta Part A, 66, 262-272. 


\section{supporting information}

Acta Cryst. (2017). C73 [https://doi.org/10.1107/S2053229617013766]

\section{A new copper(II) coordination polymer containing chains of interconnected paddle-wheel antiferromagnetic clusters}

\section{Sofiane Bouheroum, Aouatef Cherouana, Adel Beghidja, Slimane Dahaoui and Pierre Rabu}

Computing details

Data collection: CrysAlis PRO (Oxford Diffraction, 2008); cell refinement: CrysAlis PRO (Oxford Diffraction, 2008); data reduction: CrysAlis PRO (Oxford Diffraction, 2008); program(s) used to solve structure: SIR97 (Altomare et al., 1999); program(s) used to refine structure: SHELXL2014 (Sheldrick, 2015); molecular graphics: OLEX2 (Dolomanov et al., 2009); software used to prepare material for publication: OLEX2 (Dolomanov et al., 2009).

catena-Poly[[[tetrakis $\left(\mu\right.$-4-azaniumylbutanoato- $\left.\kappa^{2} \mathrm{O}: \mathrm{O}^{\prime}\right)$ dicopper(III) $\left.(\mathrm{Cu}-\mathrm{Cu})\right]-\mu$ chlorido-[diaquadichloridocopper(II)]- $\mu$-chlorido] bis(perchlorate)]

Crystal data

$\left[\mathrm{Cu}_{3} \mathrm{Cl}_{4}\left(\mathrm{C}_{4} \mathrm{H}_{9} \mathrm{NO}_{2}\right)_{4}\left(\mathrm{H}_{2} \mathrm{O}\right)_{2}\right]\left(\mathrm{ClO}_{4}\right)_{2}$

$M_{r}=979.82$

Monoclinic, $P 2_{1} / c$

Hall symbol: -P 2ybc

$a=12.946(3) \AA$

$b=12.568(3) \AA$

$c=11.044(2) \AA$

$\beta=115.18(3)^{\circ}$

$V=1626.2(7) \AA^{3}$

$Z=2$

Data collection

Oxford Diffraction KappaCCD diffractometer

Radiation source: fine-focus sealed tube Graphite monochromator $\omega$ scans

Absorption correction: integration (DeTitta, 1985)

$T_{\min }=0.720, T_{\max }=0.853$

Refinement

Refinement on $F^{2}$

Least-squares matrix: full

$R\left[F^{2}>2 \sigma\left(F^{2}\right)\right]=0.044$

$w R\left(F^{2}\right)=0.109$

$S=0.99$

19050 reflections

217 parameters

3 restraints
$F(000)=994$

$D_{\mathrm{x}}=2.001 \mathrm{Mg} \mathrm{m}^{-3}$

Mo $K \alpha$ radiation, $\lambda=0.71073 \AA$

Cell parameters from 19042 reflections

$\theta=2.6-27.7^{\circ}$

$\mu=2.52 \mathrm{~mm}^{-1}$

$T=100 \mathrm{~K}$

Prism, green

$0.1 \times 0.1 \times 0.08 \mathrm{~mm}$

19050 measured reflections

19050 independent reflections

15048 reflections with $I>2 \sigma(I)$

$R_{\text {int }}=0.038$

$\theta_{\max }=27.7^{\circ}, \theta_{\min }=2.6^{\circ}$

$h=-16 \rightarrow 16$

$k=-16 \rightarrow 16$

$l=-14 \rightarrow 14$

Primary atom site location: structure-invariant direct methods

Secondary atom site location: difference Fourier map

Hydrogen site location: difference Fourier map

$\mathrm{H}$-atom parameters constrained

$w=1 /\left[\sigma^{2}\left(F_{\mathrm{o}}^{2}\right)+(0.0667 P)^{2}\right]$

where $P=\left(F_{\mathrm{o}}^{2}+2 F_{\mathrm{c}}^{2}\right) / 3$ 
$(\Delta / \sigma)_{\max }<0.001$

$\Delta \rho_{\max }=1.26 \mathrm{e} \AA^{-3}$

$\Delta \rho_{\min }=-1.92$ e $\AA^{-3}$

Special details

Geometry. Bond distances, angles etc. have been calculated using the rounded fractional coordinates. All su's are estimated from the variances of the (full) variance-covariance matrix. The cell esds are taken into account in the estimation of distances, angles and torsion angles

Refinement. Refined as a 2-component twin.

Fractional atomic coordinates and isotropic or equivalent isotropic displacement parameters $\left(\AA^{2}\right)$

\begin{tabular}{|c|c|c|c|c|}
\hline & $x$ & $y$ & $z$ & $U_{\text {iso }} * / U_{\text {eq }}$ \\
\hline $\mathrm{Cu} 1$ & $0.99887(8)$ & $0.95931(5)$ & $0.38914(7)$ & $0.0087(2)$ \\
\hline $\mathrm{Cu} 2$ & 1.00000 & 1.00000 & 0.00000 & $0.0236(4)$ \\
\hline $\mathrm{C} 12$ & $0.80176(13)$ & $0.99175(15)$ & $-0.11378(19)$ & $0.0213(5)$ \\
\hline $\mathrm{Cl} 3$ & $0.98967(15)$ & $0.86597(11)$ & $0.19198(15)$ & $0.0141(4)$ \\
\hline $\mathrm{O} 1$ & $1.1161(4)$ & $0.8638(4)$ & $0.5140(5)$ & $0.0208(17)$ \\
\hline $\mathrm{O} 1 \mathrm{~W}$ & $0.9850(5)$ & $1.1296(3)$ & $0.1010(5)$ & $0.0243(16)$ \\
\hline $\mathrm{O} 2$ & $0.8865(5)$ & $1.0727(4)$ & $0.2988(5)$ & 0.0187 (17) \\
\hline $\mathrm{O} 3$ & $0.8778(4)$ & $0.8696(4)$ & $0.3998(5)$ & $0.0188(17)$ \\
\hline $\mathrm{O} 4$ & $1.1208(5)$ & $1.0625(4)$ & $0.4120(5)$ & 0.0205 (17) \\
\hline N1 & $1.2977(5)$ & $0.5897(5)$ & $0.9106(6)$ & $0.0156(19)$ \\
\hline $\mathrm{N} 2$ & $0.7144(5)$ & $0.5913(5)$ & $0.6050(5)$ & 0.0139 (19) \\
\hline $\mathrm{C} 1$ & $1.1480(6)$ & $0.8635(6)$ & $0.6389(7)$ & $0.010(2)$ \\
\hline $\mathrm{C} 2$ & $1.2308(6)$ & $0.7758(5)$ & $0.7141(7)$ & 0.0139 (19) \\
\hline $\mathrm{C} 3$ & $1.2774(7)$ & $0.7837(6)$ & $0.8644(8)$ & $0.014(2)$ \\
\hline $\mathrm{C} 4$ & $1.3600(6)$ & $0.6939(5)$ & $0.9343(8)$ & $0.013(2)$ \\
\hline $\mathrm{C} 5$ & $0.8440(6)$ & $0.8730(6)$ & $0.4908(7)$ & $0.013(2)$ \\
\hline C6 & $0.7515(6)$ & $0.7943(5)$ & $0.4807(7)$ & $0.012(2)$ \\
\hline $\mathrm{C} 7$ & $0.7261(7)$ & $0.7881(6)$ & $0.6029(7)$ & $0.016(2)$ \\
\hline $\mathrm{C} 8$ & $0.6543(6)$ & $0.6931(5)$ & $0.6004(8)$ & $0.014(2)$ \\
\hline $\mathrm{Cl1}$ & $0.51942(12)$ & $0.47535(11)$ & $0.74998(16)$ & $0.0153(5)$ \\
\hline O5 & $0.4947(4)$ & $0.5097(3)$ & $0.8587(5)$ & $0.0218(17)$ \\
\hline O6 & $0.4636(4)$ & $0.5401(5)$ & $0.6359(5)$ & $0.0306(17)$ \\
\hline $\mathrm{O} 7$ & $0.6421(3)$ & $0.4820(3)$ & $0.7932(5)$ & $0.0189(16)$ \\
\hline O8 & $0.4841(4)$ & $0.3669(4)$ & $0.7191(5)$ & 0.0277 (17) \\
\hline H1WA & 0.98700 & 1.13870 & 0.19200 & $0.0300 *$ \\
\hline $\mathrm{H} 1 \mathrm{~A}$ & 1.26710 & 0.57390 & 0.82180 & $0.0190^{*}$ \\
\hline H1B & 1.24090 & 0.59460 & 0.93820 & $0.0190^{*}$ \\
\hline $\mathrm{H} 1 \mathrm{C}$ & 1.34730 & 0.53750 & 0.95750 & $0.0190^{*}$ \\
\hline H1WB & 0.98210 & 1.20340 & 0.06870 & $0.0300^{*}$ \\
\hline $\mathrm{H} 2 \mathrm{~A}$ & 0.69960 & 0.57060 & 0.52030 & $0.0170^{*}$ \\
\hline $\mathrm{H} 2 \mathrm{~B}$ & 0.68940 & 0.54040 & 0.64480 & $0.0170^{*}$ \\
\hline $\mathrm{H} 2 \mathrm{C}$ & 0.79090 & 0.60060 & 0.65280 & $0.0170^{*}$ \\
\hline $\mathrm{H} 2 \mathrm{D}$ & 1.19180 & 0.70640 & 0.68550 & $0.0160^{*}$ \\
\hline $\mathrm{H} 2 \mathrm{E}$ & 1.29550 & 0.77710 & 0.68880 & $0.0160^{*}$ \\
\hline $\mathrm{H} 3 \mathrm{~A}$ & 1.21320 & 0.78180 & 0.89070 & $0.0170^{*}$ \\
\hline H3B & 1.31700 & 0.85280 & 0.89400 & $0.0170 *$ \\
\hline
\end{tabular}




\begin{tabular}{lllll} 
H4A & 1.41910 & 0.69000 & 0.89990 & $0.0160^{*}$ \\
H4B & 1.39850 & 0.70850 & 1.03150 & $0.0160^{*}$ \\
H6A & 0.77430 & 0.72260 & 0.46370 & $0.0140^{*}$ \\
H6B & 0.68020 & 0.81360 & 0.40220 & $0.0140^{*}$ \\
H7A & 0.79900 & 0.78480 & 0.68440 & $0.0190^{*}$ \\
H7B & 0.68580 & 0.85370 & 0.60800 & $0.0190^{*}$ \\
H8A & 0.63500 & 0.69660 & 0.67800 & $0.0160^{*}$ \\
H8B & 0.58210 & 0.69510 & 0.51790 & $0.0160^{*}$ \\
\hline
\end{tabular}

Atomic displacement parameters $\left(\AA^{2}\right)$

\begin{tabular}{lllllll}
\hline & $U^{11}$ & $U^{22}$ & $U^{33}$ & $U^{12}$ & $U^{13}$ & $U^{23}$ \\
\hline $\mathrm{Cu} 1$ & $0.0090(3)$ & $0.0082(3)$ & $0.0092(5)$ & $0.0004(4)$ & $0.0041(5)$ & $0.0003(3)$ \\
$\mathrm{C} 22$ & $0.0205(5)$ & $0.0270(6)$ & $0.0234(8)$ & $0.0014(7)$ & $0.0095(8)$ & $-0.0013(5)$ \\
$\mathrm{C} 2$ & $0.0209(7)$ & $0.0233(8)$ & $0.0184(10)$ & $-0.0014(8)$ & $0.0072(8)$ & $0.0037(7)$ \\
$\mathrm{Cl} 3$ & $0.0136(7)$ & $0.0187(7)$ & $0.0110(8)$ & $0.0012(7)$ & $0.0062(8)$ & $-0.0022(5)$ \\
O1 & $0.025(3)$ & $0.027(3)$ & $0.009(3)$ & $0.015(3)$ & $0.006(2)$ & $0.004(2)$ \\
O1W & $0.036(3)$ & $0.021(2)$ & $0.020(3)$ & $0.002(2)$ & $0.016(3)$ & $0.0000(19)$ \\
O2 & $0.027(3)$ & $0.016(3)$ & $0.010(3)$ & $0.009(2)$ & $0.005(2)$ & $-0.001(2)$ \\
O3 & $0.019(3)$ & $0.026(3)$ & $0.016(3)$ & $-0.013(2)$ & $0.012(2)$ & $-0.010(2)$ \\
O4 & $0.027(3)$ & $0.019(3)$ & $0.023(3)$ & $-0.011(2)$ & $0.018(2)$ & $-0.010(2)$ \\
N1 & $0.020(3)$ & $0.009(4)$ & $0.016(3)$ & $0.001(2)$ & $0.006(3)$ & $0.000(2)$ \\
N2 & $0.013(3)$ & $0.018(4)$ & $0.009(3)$ & $0.000(2)$ & $0.003(2)$ & $0.005(2)$ \\
C1 & $0.007(3)$ & $0.008(4)$ & $0.017(4)$ & $-0.001(3)$ & $0.006(3)$ & $0.003(3)$ \\
C2 & $0.017(3)$ & $0.010(3)$ & $0.014(4)$ & $0.002(3)$ & $0.006(3)$ & $0.000(3)$ \\
C3 & $0.019(4)$ & $0.010(4)$ & $0.012(4)$ & $0.002(3)$ & $0.005(3)$ & $-0.002(3)$ \\
C4 & $0.013(3)$ & $0.012(4)$ & $0.016(4)$ & $-0.002(3)$ & $0.007(3)$ & $-0.001(3)$ \\
C5 & $0.010(3)$ & $0.013(4)$ & $0.016(4)$ & $0.007(3)$ & $0.005(3)$ & $0.006(3)$ \\
C6 & $0.014(3)$ & $0.009(4)$ & $0.012(4)$ & $-0.002(2)$ & $0.005(3)$ & $0.001(3)$ \\
C7 & $0.017(4)$ & $0.016(4)$ & $0.020(4)$ & $-0.002(3)$ & $0.013(3)$ & $0.001(3)$ \\
C8 & $0.014(3)$ & $0.011(4)$ & $0.018(4)$ & $-0.002(3)$ & $0.009(3)$ & $0.001(3)$ \\
C11 & $0.0135(7)$ & $0.0211(9)$ & $0.0096(8)$ & $-0.0012(6)$ & $0.0033(7)$ & $-0.0001(7)$ \\
O5 & $0.016(3)$ & $0.031(3)$ & $0.019(3)$ & $0.0065(19)$ & $0.008(2)$ & $-0.004(2)$ \\
O6 & $0.025(3)$ & $0.045(3)$ & $0.015(3)$ & $0.001(2)$ & $0.002(2)$ & $0.020(3)$ \\
O7 & $0.013(2)$ & $0.021(3)$ & $0.024(3)$ & $0.0007(19)$ & $0.009(2)$ & $0.000(2)$ \\
O8 & $0.031(3)$ & $0.021(3)$ & $0.031(3)$ & $-0.010(2)$ & $0.013(3)$ & $-0.008(2)$ \\
& & & & & & \\
\hline & & & & & &
\end{tabular}

Geometric parameters $\left(\AA,{ }^{\circ}\right)$

\begin{tabular}{llll}
\hline $\mathrm{Cu} 1-\mathrm{Cl} 3$ & $2.4312(18)$ & $\mathrm{N} 1-\mathrm{H} 1 \mathrm{C}$ & 0.9100 \\
$\mathrm{Cu} 1-\mathrm{O} 1$ & $1.966(5)$ & $\mathrm{N} 1-\mathrm{H} 1 \mathrm{~A}$ & 0.9100 \\
$\mathrm{Cu} 1-\mathrm{O} 2$ & $1.977(6)$ & $\mathrm{N} 2-\mathrm{H} 2 \mathrm{C}$ & 0.9100 \\
$\mathrm{Cu} 1-\mathrm{O} 3$ & $1.975(6)$ & $\mathrm{N} 2-\mathrm{H} 2 \mathrm{~A}$ & 0.9100 \\
$\mathrm{Cu} 1-\mathrm{O} 4$ & $1.974(6)$ & $\mathrm{N} 2-\mathrm{H} 2 \mathrm{~B}$ & 0.9100 \\
$\mathrm{Cu} 2-\mathrm{Cl} 2$ & $2.331(2)$ & $\mathrm{C} 1-\mathrm{C} 2$ & $1.515(10)$ \\
$\mathrm{Cu} 2-\mathrm{Cl} 3$ & $2.7554(17)$ & $\mathrm{C} 2-\mathrm{C} 3$ & $1.509(11)$ \\
$\mathrm{Cu} 2-\mathrm{O} 1 W$ & $2.030(5)$ & $\mathrm{C} 3-\mathrm{C} 4$ & $1.520(11)$ \\
$\mathrm{Cu} 2-\mathrm{Cl2}{ }^{\mathrm{i}}$ & $2.331(2)$ & $\mathrm{C} 5-\mathrm{C} 6$ & $1.520(11)$
\end{tabular}




\begin{tabular}{|c|c|c|c|}
\hline $\mathrm{Cu} 2-\mathrm{Cl}^{\mathrm{i}}$ & $2.7554(17)$ & $\mathrm{C} 6-\mathrm{C} 7$ & $1.521(11)$ \\
\hline $\mathrm{Cu} 2-\mathrm{O}_{1} \mathrm{~W}^{\mathrm{i}}$ & $2.030(5)$ & $\mathrm{C} 7-\mathrm{C} 8$ & $1.506(11)$ \\
\hline $\mathrm{Cl} 1-\mathrm{O} 7$ & $1.453(5)$ & $\mathrm{C} 2-\mathrm{H} 2 \mathrm{E}$ & 0.9900 \\
\hline $\mathrm{Cl1}-\mathrm{O} 5$ & $1.434(5)$ & $\mathrm{C} 2-\mathrm{H} 2 \mathrm{D}$ & 0.9900 \\
\hline $\mathrm{Cl1}-\mathrm{O} 6$ & $1.413(6)$ & $\mathrm{C} 3-\mathrm{H} 3 \mathrm{~B}$ & 0.9900 \\
\hline $\mathrm{Cl1}-\mathrm{O} 8$ & $1.432(5)$ & $\mathrm{C} 3-\mathrm{H} 3 \mathrm{~A}$ & 0.9900 \\
\hline $\mathrm{O} 1-\mathrm{C} 1$ & $1.260(9)$ & $\mathrm{C} 4-\mathrm{H} 4 \mathrm{~A}$ & 0.9900 \\
\hline $\mathrm{O} 2-\mathrm{C} 1^{\mathrm{ii}}$ & $1.256(10)$ & $\mathrm{C} 4-\mathrm{H} 4 \mathrm{~B}$ & 0.9900 \\
\hline $\mathrm{O} 3-\mathrm{C} 5$ & $1.256(9)$ & C6-H6A & 0.9900 \\
\hline $\mathrm{O} 4-\mathrm{C} 5^{\mathrm{ii}}$ & $1.265(9)$ & C6-H6B & 0.9900 \\
\hline $\mathrm{O} 1 \mathrm{~W}-\mathrm{H} 1 \mathrm{WB}$ & 0.9900 & $\mathrm{C} 7-\mathrm{H} 7 \mathrm{~B}$ & 0.9900 \\
\hline $\mathrm{O} 1 \mathrm{~W}-\mathrm{H} 1 \mathrm{WA}$ & 1.0000 & C7-H7A & 0.9900 \\
\hline $\mathrm{N} 1-\mathrm{C} 4$ & $1.502(9)$ & $\mathrm{C} 8-\mathrm{H} 8 \mathrm{~A}$ & 0.9900 \\
\hline $\mathrm{N} 2-\mathrm{C} 8$ & $1.487(9)$ & $\mathrm{C} 8-\mathrm{H} 8 \mathrm{~B}$ & 0.9900 \\
\hline $\mathrm{N} 1-\mathrm{H} 1 \mathrm{~B}$ & 0.9100 & & \\
\hline $\mathrm{Cu} 1 \cdots \mathrm{O} 1 \mathrm{~W}$ & $3.775(5)$ & $\mathrm{O} 8 \cdots \mathrm{H} 2 \mathrm{~A}^{\mathrm{x}}$ & 2.8100 \\
\hline $\mathrm{Cu} 1 \cdots \mathrm{N} 2^{\mathrm{iii}}$ & $3.739(6)$ & $\mathrm{O} 8 \cdots \mathrm{H} 2 \mathrm{E}^{\mathrm{xiii}}$ & 2.8200 \\
\hline $\mathrm{Cu} 1 \cdots \mathrm{O} 3^{\mathrm{ii}}$ & $3.072(5)$ & $\mathrm{O} 8 \cdots \mathrm{H} 4 \mathrm{~B}^{\mathrm{vii}}$ & 2.6900 \\
\hline $\mathrm{Cu} 1 \cdots \mathrm{O} 1^{\mathrm{ii}}$ & $3.108(5)$ & $\mathrm{O} 8 \cdots \mathrm{H}^{\prime} \mathrm{B}^{\mathrm{x}}$ & 2.5100 \\
\hline $\mathrm{Cu} 1 \cdots \mathrm{O} 2^{\mathrm{ii}}$ & $3.145(5)$ & $\mathrm{N} 1 \cdots \mathrm{Cl} 2^{\mathrm{iv}}$ & $3.214(6)$ \\
\hline $\mathrm{Cu} 1 \cdots \mathrm{O} 4^{\mathrm{ii}}$ & $3.193(6)$ & $\mathrm{N} 1 \cdots \mathrm{O} 5^{\mathrm{vii}}$ & $3.074(8)$ \\
\hline $\mathrm{Cu} 1 \cdots \mathrm{N} 1^{\mathrm{iii}}$ & $3.824(7)$ & $\mathrm{N} 1 \cdots \mathrm{O} 7^{\mathrm{vii}}$ & $3.155(8)$ \\
\hline $\mathrm{Cu} 1 \cdots \mathrm{H} 1 \mathrm{WB}^{\mathrm{iv}}$ & 3.2400 & $\mathrm{~N} 1 \cdots \mathrm{Cu} 1^{\mathrm{xii}}$ & $3.824(7)$ \\
\hline Cu1 $\cdots$ H1WA & 3.0900 & $\mathrm{~N} 1 \cdots \mathrm{O} 1^{\mathrm{xii}}$ & $3.075(9)$ \\
\hline $\mathrm{Cu} 1 \cdots \mathrm{H} 1 \mathrm{~B}^{\mathrm{iii}}$ & 3.0200 & $\mathrm{~N} 1 \cdots \mathrm{O} 5^{\mathrm{xv}}$ & $3.015(9)$ \\
\hline $\mathrm{Cu} 1 \cdots \mathrm{H} 2 \mathrm{C}^{\mathrm{iii}}$ & 2.9400 & $\mathrm{~N} 1 \cdots \mathrm{O} 4^{\mathrm{xii}}$ & $2.989(9)$ \\
\hline $\mathrm{Cu} 2 \cdots \mathrm{H} 2 \mathrm{D}^{\mathrm{v}}$ & 3.5700 & $\mathrm{~N} 2 \cdots \mathrm{O} 7$ & $2.956(8)$ \\
\hline $\mathrm{Cu} 2 \cdots \mathrm{H} 2 \mathrm{D}^{\mathrm{iii}}$ & 3.5700 & $\mathrm{~N} 2 \cdots \mathrm{O} 6^{\mathrm{x}}$ & $3.146(8)$ \\
\hline $\mathrm{Cl} 2 \cdots \mathrm{Cl} 3$ & $3.582(3)$ & $\mathrm{N} 2 \cdots \mathrm{Cu} 1^{\mathrm{xii}}$ & $3.739(6)$ \\
\hline $\mathrm{Cl} 2 \cdots \mathrm{O} 1 \mathrm{~W}$ & $3.077(5)$ & $\mathrm{N} 2 \cdots \mathrm{Cl} 2^{\mathrm{xii}}$ & $3.245(6)$ \\
\hline $\mathrm{Cl} 2 \cdots \mathrm{O}^{\mathrm{vi}}$ & $3.394(6)$ & $\mathrm{N} 2 \cdots \mathrm{Cl} 3^{\mathrm{xii}}$ & $3.316(7)$ \\
\hline $\mathrm{Cl} 2 \cdots \mathrm{N} 1^{\mathrm{v}}$ & $3.214(6)$ & $\mathrm{N} 2 \cdots \mathrm{O} 2^{\mathrm{xii}}$ & $3.120(8)$ \\
\hline $\mathrm{Cl} 2 \cdots \mathrm{O} 1 \mathrm{~W}^{\mathrm{i}}$ & $3.104(7)$ & $\mathrm{N} 2 \cdots \mathrm{O} 3^{\mathrm{xii}}$ & $3.075(7)$ \\
\hline $\mathrm{Cl} 2 \cdots \mathrm{N} 2^{\mathrm{iii}}$ & $3.245(6)$ & $\mathrm{N} 1 \cdots \mathrm{H} 2 \mathrm{D}$ & 2.7000 \\
\hline $\mathrm{Cl} 2 \cdots \mathrm{Cl}^{3}{ }^{\mathrm{i}}$ & $3.636(3)$ & $\mathrm{N} 2 \cdots \mathrm{H} 6 \mathrm{~A}$ & 2.6100 \\
\hline $\mathrm{Cl} 3 \cdots \mathrm{O} 1 \mathrm{~W}^{\mathrm{i}}$ & $3.389(6)$ & $\mathrm{C} 1 \cdots \mathrm{O} 7^{\mathrm{xvi}}$ & $2.904(9)$ \\
\hline $\mathrm{Cl} 3 \cdots \mathrm{N} 22^{\mathrm{iii}}$ & $3.316(7)$ & $\mathrm{C} 1 \cdots \mathrm{C} 5$ & $3.564(12)$ \\
\hline $\mathrm{Cl} 3 \cdots \mathrm{O} 4$ & $3.373(5)$ & $\mathrm{C} 2 \cdots \mathrm{Cl}^{\mathrm{xii}}$ & $3.511(8)$ \\
\hline $\mathrm{Cl} 3 \cdots \mathrm{O} 1 \mathrm{~W}$ & $3.455(4)$ & $\mathrm{C} 2 \cdots \mathrm{O} 7^{\mathrm{xvi}}$ & $3.089(8)$ \\
\hline $\mathrm{Cl} 3 \cdots \mathrm{Cl} 2$ & $3.582(3)$ & $\mathrm{C} 4 \cdots \mathrm{O}^{\mathrm{xv}}$ & $3.215(9)$ \\
\hline $\mathrm{Cl} 3 \cdots \mathrm{O} 1$ & $3.221(5)$ & $\mathrm{C} 4 \cdots \mathrm{O} 5^{\mathrm{vii}}$ & $3.414(8)$ \\
\hline $\mathrm{Cl} 3 \cdots \mathrm{C}^{\mathrm{iii}}$ & $3.590(8)$ & $\mathrm{C} 5 \cdots \mathrm{C} 1$ & $3.564(12)$ \\
\hline $\mathrm{Cl} 3 \cdots \mathrm{O} 2$ & $3.357(6)$ & $\mathrm{C} 5 \cdots \mathrm{O} 7^{\mathrm{iii}}$ & $3.172(9)$ \\
\hline $\mathrm{Cl} 3 \cdots \mathrm{O} 3$ & $3.193(6)$ & $\mathrm{C} 6 \cdots \mathrm{Cl} 3^{\mathrm{xii}}$ & $3.590(8)$ \\
\hline $\mathrm{Cl} 3 \cdots \mathrm{Cl} 2^{\mathrm{i}}$ & $3.636(3)$ & $\mathrm{C} 8 \cdots \mathrm{O}^{\mathrm{x}}$ & $3.294(9)$ \\
\hline $\mathrm{Cl} 3 \cdots \mathrm{C} 2^{\mathrm{iii}}$ & $3.511(8)$ & C8‥O6 & $3.282(10)$ \\
\hline $\mathrm{C} 11 \cdots \mathrm{H} 1 \mathrm{C}^{\mathrm{vii}}$ & 2.9500 & $\mathrm{C} 1 \cdots \mathrm{H} 1 \mathrm{WA}^{\mathrm{ii}}$ & 3.0500 \\
\hline
\end{tabular}




\begin{tabular}{|c|c|c|c|}
\hline $\mathrm{C} 11 \cdots \mathrm{H} 2 \mathrm{~B}$ & 3.0100 & $\mathrm{C} 1 \cdots \mathrm{H} 1 \mathrm{WB}^{\mathrm{iv}}$ & 2.9800 \\
\hline $\mathrm{C} 12 \cdots \mathrm{H} 6 \mathrm{~A}^{\mathrm{iii}}$ & 2.8900 & $\mathrm{C} 1 \cdots \mathrm{H} 1 \mathrm{~B}^{\mathrm{iii}}$ & 2.9800 \\
\hline $\mathrm{Cl} 2 \cdots \mathrm{H} 2 \mathrm{~A}^{\mathrm{iii}}$ & 2.4900 & $\mathrm{C} 2 \cdots \mathrm{H} 1 \mathrm{~A}$ & 2.7600 \\
\hline $\mathrm{Cl} 2 \cdots \mathrm{H} 1 \mathrm{~A}^{\mathrm{v}}$ & 2.3200 & $\mathrm{C} 4 \cdots \mathrm{H}_{8} 8 \mathrm{~B}^{\mathrm{xvii}}$ & 2.9700 \\
\hline $\mathrm{C} 12 \cdots \mathrm{H} 2 \mathrm{D}^{\mathrm{v}}$ & 2.8200 & $\mathrm{C} 6 \cdots \mathrm{H} 2 \mathrm{C}$ & 3.0000 \\
\hline $\mathrm{Cl} 3 \cdots \mathrm{H} 1 \mathrm{WA}^{\mathrm{iv}}$ & 3.0900 & C6 $6 \cdots \mathrm{H} 2 \mathrm{~A}$ & 2.9700 \\
\hline $\mathrm{Cl} 3 \cdots \mathrm{H} 6 \mathrm{~A}^{\mathrm{iii}}$ & 3.0600 & $\mathrm{C} 6 \cdots \mathrm{H} 8 \mathrm{~A}^{\mathrm{iii}}$ & 3.0300 \\
\hline $\mathrm{Cl} 3 \cdots \mathrm{H} 7 \mathrm{~A}^{\mathrm{iii}}$ & 3.0800 & $\mathrm{H} 1 \mathrm{WA} \cdots \mathrm{C} 1^{\mathrm{ii}}$ & 3.0500 \\
\hline $\mathrm{Cl} 3 \cdots \mathrm{H} 2 \mathrm{C}^{\mathrm{iii}}$ & 2.4600 & $\mathrm{H} 1 \mathrm{WA} \cdots \mathrm{O} 4$ & 2.5000 \\
\hline $\mathrm{Cl} 3 \cdots \mathrm{H} 2 \mathrm{D}^{\mathrm{iii}}$ & 2.8000 & $\mathrm{H} 1 \mathrm{WA} \cdots \mathrm{Cl}^{\mathrm{v}}$ & 3.0900 \\
\hline $\mathrm{O} 1 \cdots \mathrm{Cl} 3$ & $3.221(5)$ & $\mathrm{H} 1 \mathrm{WA} \cdots \mathrm{Cu} 1$ & 3.0900 \\
\hline $\mathrm{O} 1 \cdots \mathrm{N} 1^{\mathrm{iii}}$ & $3.075(9)$ & $\mathrm{H} 1 \mathrm{WA} \cdots \mathrm{O} 2$ & 2.2500 \\
\hline $\mathrm{O} 1 \cdots \mathrm{O} 3$ & $2.793(8)$ & $\mathrm{H} 1 \mathrm{WA} \cdots \mathrm{H} 3 \mathrm{~A}^{\mathrm{ii}}$ & 2.5600 \\
\hline $\mathrm{O} 1 \cdots \mathrm{O} 4$ & $2.751(7)$ & $\mathrm{H} 1 \mathrm{~A} \cdots \mathrm{Cl} 2^{\mathrm{iv}}$ & 2.3200 \\
\hline $\mathrm{O} 1 \cdots \mathrm{C} 5^{\mathrm{ii}}$ & $3.352(9)$ & $\mathrm{H} 1 \mathrm{~A} \cdots \mathrm{O} 5^{\mathrm{xv}}$ & 2.9100 \\
\hline $\mathrm{O} 1 \cdots \mathrm{Cu} 1^{\mathrm{ii}}$ & $3.108(5)$ & $\mathrm{H} 1 \mathrm{~A} \cdots \mathrm{C} 2$ & 2.7600 \\
\hline $\mathrm{O} 1 \mathrm{~W} \cdots \mathrm{Cl} 2^{\mathrm{i}}$ & $3.104(7)$ & $\mathrm{H} 1 \mathrm{~A} \cdots \mathrm{H} 2 \mathrm{D}$ & 2.1800 \\
\hline $\mathrm{O} 1 \mathrm{~W} \cdots \mathrm{Cl} 2$ & $3.077(5)$ & $\mathrm{H} 1 \mathrm{~B} \cdots \mathrm{O} 7^{\mathrm{vii}}$ & 2.8600 \\
\hline $\mathrm{O} 1 \mathrm{~W} \cdots \mathrm{O} 4$ & $3.234(7)$ & H1B $\cdots C u 1^{\text {xii }}$ & 3.0200 \\
\hline $\mathrm{O} 1 \mathrm{~W} \cdots \mathrm{Cl} 3^{\mathrm{i}}$ & $3.389(6)$ & H1B $\cdots H 3 A$ & 2.4000 \\
\hline $\mathrm{O} 1 \mathrm{~W} \cdots \mathrm{Cu} 1$ & $3.775(5)$ & $\mathrm{H} 1 \mathrm{~B} \cdots \mathrm{O} 1^{\mathrm{xii}}$ & 2.1800 \\
\hline $\mathrm{O} 1 \mathrm{~W} \cdots \mathrm{O} 2$ & $3.046(9)$ & $\mathrm{H} 1 \mathrm{~B} \cdots \mathrm{O} 4^{\mathrm{xii}}$ & 2.4500 \\
\hline $\mathrm{O} 1 \mathrm{~W} \cdots \mathrm{Cl} 3$ & $3.455(4)$ & $\mathrm{H} 1 \mathrm{~B} \cdots \mathrm{C} 1^{\mathrm{xii}}$ & 2.9800 \\
\hline $\mathrm{O} 2 \cdots \mathrm{O} 1 \mathrm{~W}$ & $3.046(9)$ & $\mathrm{H} 1 \mathrm{C} \cdots \mathrm{H} \mathrm{B}^{\mathrm{xiii}}$ & 2.4000 \\
\hline $\mathrm{O} 2 \cdots \mathrm{C} 5^{\mathrm{ii}}$ & $3.338(10)$ & $\mathrm{H} 1 \mathrm{C} \cdots \mathrm{Cl1}{ }^{\mathrm{vii}}$ & 2.9500 \\
\hline $\mathrm{O} 2 \cdots \mathrm{O} 3$ & 2.807 (7) & $\mathrm{H} 1 \mathrm{C} \cdots \mathrm{O} 5^{\text {vii }}$ & 2.2600 \\
\hline $\mathrm{O} 2 \cdots \mathrm{Cu} 1^{\mathrm{ii}}$ & $3.145(5)$ & $\mathrm{H} 1 \mathrm{C} \cdots \mathrm{O} 5^{\mathrm{xv}}$ & 2.5900 \\
\hline $\mathrm{O} 2 \cdots \mathrm{N} 2^{\mathrm{iii}}$ & $3.120(8)$ & $\mathrm{H} 1 \mathrm{C} \cdots \mathrm{O} 7^{\mathrm{vii}}$ & 2.7100 \\
\hline $\mathrm{O} 2 \cdots \mathrm{Cl} 3$ & $3.357(6)$ & $\mathrm{H} 1 \mathrm{WB} \cdots \mathrm{C} 1^{v}$ & 2.9800 \\
\hline $\mathrm{O} 2 \cdots \mathrm{O} 4$ & $2.748(9)$ & $\mathrm{H} 1 \mathrm{WB} \cdots \mathrm{O} 1^{\mathrm{v}}$ & 2.3500 \\
\hline $\mathrm{O} 2 \cdots \mathrm{O} 7^{\mathrm{iii}}$ & $3.213(8)$ & $\mathrm{H} 1 \mathrm{WB} \cdots \mathrm{O} 3^{\mathrm{v}}$ & 2.6900 \\
\hline $\mathrm{O} 3 \cdots \mathrm{O} 1$ & $2.793(8)$ & $\mathrm{H} 1 \mathrm{WB} \cdots \mathrm{Cu} 1^{\mathrm{v}}$ & 3.2400 \\
\hline $\mathrm{O} 3 \cdots \mathrm{C} 1$ & $3.370(9)$ & $\mathrm{H} 2 \mathrm{~A} \cdots \mathrm{C} 6$ & 2.9700 \\
\hline $\mathrm{O} 3 \cdots \mathrm{N} 2^{\mathrm{iii}}$ & $3.075(7)$ & $\mathrm{H} 2 \mathrm{~A} \cdots \mathrm{H} 6 \mathrm{~A}$ & 2.3400 \\
\hline $\mathrm{O} 3 \cdots \mathrm{Cl} 3$ & $3.193(6)$ & $\mathrm{H} 2 \mathrm{~A} \cdots \mathrm{O} 6^{\mathrm{x}}$ & 2.5000 \\
\hline $\mathrm{O} 3 \cdots \mathrm{Cu} 1^{\mathrm{ii}}$ & $3.072(5)$ & $\mathrm{H} 2 \mathrm{~A}^{\cdots} \mathrm{O}^{\mathrm{x}}$ & 2.8100 \\
\hline $\mathrm{O} 3 \cdots \mathrm{O} 2$ & $2.807(7)$ & $\mathrm{H} 2 \mathrm{~A} \cdots \mathrm{Cl} 2^{\mathrm{xii}}$ & 2.4900 \\
\hline $\mathrm{O} 3 \cdots \mathrm{C} 1^{\mathrm{ii}}$ & $3.380(9)$ & $\mathrm{H} 2 \mathrm{~B} \cdots \mathrm{O} 7$ & 2.1100 \\
\hline $\mathrm{O} 4 \cdots \mathrm{C} 1^{\mathrm{ii}}$ & $3.410(11)$ & $\mathrm{H} 2 \mathrm{~B} \cdots \mathrm{O} 2^{\mathrm{xii}}$ & 2.7800 \\
\hline $\mathrm{O} 4 \cdots \mathrm{Cu} 1^{\mathrm{ii}}$ & $3.193(6)$ & $\mathrm{H} 2 \mathrm{~B} \cdots \mathrm{O} 6$ & 2.8800 \\
\hline $\mathrm{O} 4 \cdots \mathrm{O} 2$ & $2.748(9)$ & H2B $\cdots H 3 B^{\text {xiii }}$ & 2.3900 \\
\hline $\mathrm{O} 4 \cdots \mathrm{O} 1 \mathrm{~W}$ & $3.234(7)$ & $\mathrm{H} 2 \mathrm{~B} \cdots \mathrm{Cl1}$ & 3.0100 \\
\hline $\mathrm{O} 4 \cdots \mathrm{N} 1^{\mathrm{iii}}$ & $2.989(9)$ & $\mathrm{H} 2 \mathrm{C} \cdots \mathrm{C} 6$ & 3.0000 \\
\hline $\mathrm{O} 4 \cdots \mathrm{Cl} 3$ & $3.373(5)$ & $\mathrm{H} 2 \mathrm{C} \cdots \mathrm{Cl} 3^{\mathrm{xii}}$ & 2.4600 \\
\hline $\mathrm{O} 4 \cdots \mathrm{O} 1$ & $2.751(7)$ & $\mathrm{H} 2 \mathrm{C} \cdots \mathrm{O} 2^{\mathrm{xii}}$ & 2.6800 \\
\hline $\mathrm{O} 5 \cdots \mathrm{O} 5^{\text {viii }}$ & $3.075(7)$ & $\mathrm{H} 2 \mathrm{C} \cdots \mathrm{O} 3^{\mathrm{xii}}$ & 2.5000 \\
\hline $\mathrm{O} 5 \cdots \mathrm{N} 1^{\mathrm{vii}}$ & $3.074(8)$ & $\mathrm{H} 2 \mathrm{C} \cdots \mathrm{H} 7 \mathrm{~A}$ & 2.3400 \\
\hline $\mathrm{O} 5 \cdots \mathrm{N} 1^{\mathrm{ix}}$ & $3.015(9)$ & $\mathrm{H} 2 \mathrm{C} \cdots \mathrm{Cu} 1^{\mathrm{xii}}$ & 2.9400 \\
\hline
\end{tabular}




\begin{tabular}{|c|c|c|c|}
\hline $\mathrm{O} 5 \cdots \mathrm{C} 4^{\mathrm{ix}}$ & $3.215(9)$ & $\mathrm{H} 2 \mathrm{C} \cdots \mathrm{H} 6 \mathrm{~A}$ & 2.5300 \\
\hline $\mathrm{O} 5 \cdots \mathrm{C}^{\mathrm{vii}}$ & $3.414(8)$ & $\mathrm{H} 2 \mathrm{D} \cdots \mathrm{N} 1$ & 2.7000 \\
\hline O6 $\cdots N 2^{x}$ & $3.146(8)$ & $\mathrm{H} 2 \mathrm{D} \cdots \mathrm{H} 1 \mathrm{~A}$ & 2.1800 \\
\hline $\mathrm{O} 6 \cdots \mathrm{C} 8$ & $3.282(10)$ & $\mathrm{H} 2 \mathrm{D} \cdots \mathrm{Cl}^{\mathrm{xii}}$ & 2.8000 \\
\hline $\mathrm{O} 6 \cdots \mathrm{Cl}^{\mathrm{xi}}$ & $3.394(6)$ & $\mathrm{H} 2 \mathrm{D} \cdots \mathrm{Cu} 2^{\mathrm{iv}}$ & 3.5700 \\
\hline $\mathrm{O} 7 \cdots \mathrm{O} 2^{\mathrm{xii}}$ & $3.213(8)$ & $\mathrm{H} 2 \mathrm{D} \cdots \mathrm{Cl} 2^{\mathrm{iv}}$ & 2.8200 \\
\hline $\mathrm{O} 7 \cdots \mathrm{C}^{\mathrm{xii}}$ & $3.172(9)$ & $\mathrm{H} 2 \mathrm{D} \cdots \mathrm{Cu} 2^{\mathrm{xii}}$ & 3.5700 \\
\hline $\mathrm{O} 7 \cdots \mathrm{N} 2$ & $2.956(8)$ & 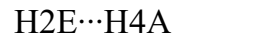 & 2.4500 \\
\hline $\mathrm{O} 7 \cdots \mathrm{C} 2^{\mathrm{xiii}}$ & $3.089(8)$ & $\mathrm{H} 2 \mathrm{E} \cdots \mathrm{O} 7^{\mathrm{xvi}}$ & 2.6800 \\
\hline $\mathrm{O} 7 \cdots \mathrm{N} 1^{\mathrm{vii}}$ & $3.155(8)$ & $\mathrm{H} 2 \mathrm{E} \cdots \mathrm{O} 8^{\mathrm{xvi}}$ & 2.8200 \\
\hline $\mathrm{O} 7 \cdots \mathrm{C} 1^{\mathrm{xiii}}$ & $2.904(9)$ & $\mathrm{H} 3 \mathrm{~A} \cdots \mathrm{O} 1^{\mathrm{xii}}$ & 2.8700 \\
\hline $\mathrm{O} 8 \cdots \mathrm{C}^{\mathrm{x}}$ & $3.294(9)$ & $\mathrm{H} 3 \mathrm{~A} \cdots \mathrm{H} 1 \mathrm{WA}^{\mathrm{ii}}$ & 2.5600 \\
\hline $\mathrm{O} 1 \cdots \mathrm{H} 1 \mathrm{~B}^{\mathrm{iii}}$ & 2.1800 & $\mathrm{H} 3 \mathrm{~A} \cdots \mathrm{O} 2^{\mathrm{ii}}$ & 2.6600 \\
\hline $\mathrm{O} 1 \cdots \mathrm{H} 3 \mathrm{~A}^{\mathrm{iii}}$ & 2.8700 & H3A $\cdots$ H1B & 2.4000 \\
\hline $\mathrm{O} 1 \cdots \mathrm{H} 1 \mathrm{WB}^{\mathrm{iv}}$ & 2.3500 & $\mathrm{H} 3 \mathrm{~A} \cdots \mathrm{O} 1 \mathrm{~W}^{\mathrm{ii}}$ & 2.8300 \\
\hline $\mathrm{O} 1 \mathrm{~W} \cdots \mathrm{H} 3 \mathrm{~A}^{\mathrm{ii}}$ & 2.8300 & $\mathrm{H} 3 \mathrm{~B} \cdots \mathrm{H} 2 \mathrm{~B}^{\mathrm{xvi}}$ & 2.3900 \\
\hline $\mathrm{O} 2 \cdots \mathrm{H} 3 \mathrm{~B}^{\mathrm{ii}}$ & 2.7500 & $\mathrm{H} 3 \mathrm{~B} \cdots \mathrm{O} 2^{\mathrm{ii}}$ & 2.7500 \\
\hline $\mathrm{O} 2 \cdots \mathrm{H} 1 \mathrm{WA}$ & 2.2500 & $\mathrm{H} 3 \mathrm{~B} \cdots \mathrm{O} 6^{\mathrm{xvii}}$ & 2.8700 \\
\hline $\mathrm{O} 2 \cdots \mathrm{H} 2 \mathrm{~B}^{\mathrm{iii}}$ & 2.7800 & $\mathrm{H} 3 \mathrm{~B} \cdots \mathrm{O}^{\mathrm{xvi}}$ & 2.8500 \\
\hline $\mathrm{O} 2 \cdots \mathrm{H} 3 \mathrm{~A}^{\mathrm{ii}}$ & 2.6600 & $\mathrm{H} 4 \mathrm{~A} \cdots \mathrm{O} 5^{\mathrm{xv}}$ & 2.5800 \\
\hline $\mathrm{O} 2 \cdots \mathrm{H} 2 \mathrm{C}^{\mathrm{iii}}$ & 2.6800 & $\mathrm{H} 4 \mathrm{~A} \cdots \mathrm{H} 2 \mathrm{E}$ & 2.4500 \\
\hline $\mathrm{O} 3 \cdots \mathrm{H} 1 \mathrm{WB}^{\mathrm{iv}}$ & 2.6900 & $\mathrm{H} 4 \mathrm{~A} \cdots \mathrm{H} 8 \mathrm{~B}^{\mathrm{xvii}}$ & 2.4300 \\
\hline $\mathrm{O} 3 \cdots \mathrm{H} \mathrm{A}^{\mathrm{iii}}$ & 2.9000 & $\mathrm{H} 4 \mathrm{~B} \cdots \mathrm{O} 8^{\mathrm{vii}}$ & 2.6900 \\
\hline $\mathrm{O} 3 \cdots \mathrm{H} 2 \mathrm{C}^{\mathrm{iii}}$ & 2.5000 & $\mathrm{H} 6 \mathrm{~A} \cdots \mathrm{H} 2 \mathrm{~A}$ & 2.3400 \\
\hline $\mathrm{O} 4 \cdots \mathrm{H} \mathrm{B}^{\mathrm{ii}}$ & 2.8100 & $\mathrm{H} 6 \mathrm{~A} \cdots \mathrm{H} 2 \mathrm{C}$ & 2.5300 \\
\hline $\mathrm{O} 4 \cdots \mathrm{H} \mathrm{A}^{\mathrm{ii}}$ & 2.6100 & $\mathrm{H} 6 \mathrm{~A} \cdots \mathrm{Cl} 2^{\mathrm{xii}}$ & 2.8900 \\
\hline $\mathrm{O} 4 \cdots \mathrm{H} 1 \mathrm{~B}^{\mathrm{iii}}$ & 2.4500 & H6A $\cdots \mathrm{N} 2$ & 2.6100 \\
\hline O4 $\cdots$ H1WA & 2.5000 & $\mathrm{H} 6 \mathrm{~A} \cdots \mathrm{Cl}^{\mathrm{xii}}$ & 3.0600 \\
\hline $\mathrm{O} 5 \cdots \mathrm{H} 1 \mathrm{C}^{\mathrm{vii}}$ & 2.2600 & H6B $\cdots H 8 A^{\mathrm{iii}}$ & 2.2900 \\
\hline O5 $\cdots H 1 C^{\text {ix }}$ & 2.5900 & $\mathrm{H} 6 \mathrm{~B} \cdots \mathrm{O} 7^{\mathrm{iii}}$ & 2.7900 \\
\hline $\mathrm{O} 5 \cdots \mathrm{H} 1 \mathrm{~A}^{\mathrm{ix}}$ & 2.9100 & $\mathrm{H} 7 \mathrm{~A} \cdots \mathrm{O} 4^{\mathrm{ii}}$ & 2.6100 \\
\hline $\mathrm{O} 5 \cdots \mathrm{H} 4 \mathrm{~A}^{\mathrm{ix}}$ & 2.5800 & $\mathrm{H} 7 \mathrm{~A} \cdots \mathrm{Cl}^{\mathrm{xii}}$ & 3.0800 \\
\hline $\mathrm{O} 6 \cdots \mathrm{H} 3 \mathrm{~B}^{\mathrm{xiv}}$ & 2.8700 & $\mathrm{H} 7 \mathrm{~A} \cdots \mathrm{O} 3^{\mathrm{xii}}$ & 2.9000 \\
\hline $\mathrm{O} 6 \cdots \mathrm{H} 2 \mathrm{~B}$ & 2.8800 & $\mathrm{H} 7 \mathrm{~A} \cdots \mathrm{H} 2 \mathrm{C}$ & 2.3400 \\
\hline $\mathrm{O} 6 \cdots \cdot \mathrm{H} 2 \mathrm{~A}^{\mathrm{x}}$ & 2.5000 & $\mathrm{H} 7 \mathrm{~B} \cdots \mathrm{H} 1 \mathrm{C}^{\mathrm{xvi}}$ & 2.4000 \\
\hline $\mathrm{O} 6 \cdots \mathrm{H} 8 \mathrm{~A}$ & 2.8500 & $\mathrm{H} 7 \mathrm{~B} \cdots \mathrm{O} 4^{\mathrm{ii}}$ & 2.8100 \\
\hline $\mathrm{O} 7 \cdots \mathrm{H} 2 \mathrm{E}^{\mathrm{xiii}}$ & 2.6800 & H8A $\cdots \mathrm{O} 6$ & 2.8500 \\
\hline $\mathrm{O} 7 \cdots \mathrm{H} 2 \mathrm{~B}$ & 2.1100 & $\mathrm{H} 8 \mathrm{~A} \cdots \mathrm{C} 6^{\mathrm{xii}}$ & 3.0300 \\
\hline $\mathrm{O} 7 \cdots \mathrm{H} \mathrm{B}^{\mathrm{xii}}$ & 2.7900 & H8A $\cdots H 6 B^{\mathrm{xii}}$ & 2.2900 \\
\hline $\mathrm{O} 7 \cdots \mathrm{H} 1 \mathrm{~B}^{\mathrm{vii}}$ & 2.8600 & $\mathrm{H} 8 \mathrm{~B} \cdots \mathrm{C} 4^{\mathrm{xiv}}$ & 2.9700 \\
\hline $\mathrm{O} 7 \cdots \mathrm{H} 3 \mathrm{~B}^{\mathrm{xiii}}$ & 2.8500 & $\mathrm{H} 8 \mathrm{~B} \cdots \mathrm{H} 4 \mathrm{~A}^{\mathrm{xiv}}$ & 2.4300 \\
\hline $\mathrm{O} 7 \cdots \mathrm{H} 1 \mathrm{C}^{\mathrm{vii}}$ & 2.7100 & $\mathrm{H} 8 \mathrm{~B} \cdots \mathrm{O} 8^{\mathrm{x}}$ & 2.5100 \\
\hline $\mathrm{Cl} 3-\mathrm{Cu} 1-\mathrm{O} 1$ & $93.59(16)$ & $\mathrm{C} 8-\mathrm{N} 2-\mathrm{H} 2 \mathrm{~A}$ & 109.00 \\
\hline $\mathrm{Cl} 3-\mathrm{Cu} 1-\mathrm{O} 2$ & 98.67 (16) & $\mathrm{C} 8-\mathrm{N} 2-\mathrm{H} 2 \mathrm{~B}$ & 109.00 \\
\hline $\mathrm{Cl} 3-\mathrm{Cu} 1-\mathrm{O} 3$ & $92.31(16)$ & $\mathrm{C} 8-\mathrm{N} 2-\mathrm{H} 2 \mathrm{C}$ & 109.00 \\
\hline $\mathrm{Cl} 3-\mathrm{Cu} 1-\mathrm{O} 4$ & $99.40(17)$ & $\mathrm{H} 2 \mathrm{~B}-\mathrm{N} 2-\mathrm{H} 2 \mathrm{C}$ & 109.00 \\
\hline $\mathrm{O} 1-\mathrm{Cu} 1-\mathrm{O} 2$ & $167.7(2)$ & $\mathrm{O} 2^{\mathrm{ii}}-\mathrm{C} 1-\mathrm{C} 2$ & $119.9(6)$ \\
\hline
\end{tabular}




\begin{tabular}{|c|c|c|c|}
\hline $\mathrm{O} 1-\mathrm{Cu} 1-\mathrm{O} 3$ & $90.3(2)$ & $\mathrm{O} 1-\mathrm{C} 1-\mathrm{C} 2$ & $115.3(7)$ \\
\hline $\mathrm{O} 1-\mathrm{Cu} 1-\mathrm{O} 4$ & $88.6(2)$ & $\mathrm{O} 1-\mathrm{C} 1-\mathrm{O} 2^{\mathrm{ii}}$ & $124.8(7)$ \\
\hline $\mathrm{O} 2-\mathrm{Cu} 1-\mathrm{O} 3$ & $90.5(2)$ & $\mathrm{C} 1-\mathrm{C} 2-\mathrm{C} 3$ & $114.4(6)$ \\
\hline $\mathrm{O} 2-\mathrm{Cu} 1-\mathrm{O} 4$ & $88.2(2)$ & $\mathrm{C} 2-\mathrm{C} 3-\mathrm{C} 4$ & $112.1(7)$ \\
\hline $\mathrm{O} 3-\mathrm{Cu} 1-\mathrm{O} 4$ & $168.3(2)$ & $\mathrm{N} 1-\mathrm{C} 4-\mathrm{C} 3$ & $110.5(7)$ \\
\hline $\mathrm{Cl} 2-\mathrm{Cu} 2-\mathrm{Cl} 3$ & $89.13(7)$ & $\mathrm{O} 3-\mathrm{C} 5-\mathrm{O} 4^{\mathrm{ii}}$ & $125.3(7)$ \\
\hline $\mathrm{Cl} 2-\mathrm{Cu} 2-\mathrm{O} 1 \mathrm{~W}$ & 89.49 (19) & $\mathrm{O} 3-\mathrm{C} 5-\mathrm{C} 6$ & $116.8(6)$ \\
\hline $\mathrm{Cl} 2-\mathrm{Cu} 2-\mathrm{Cl}^{2}$ & 180.00 & $\mathrm{O} 4^{\mathrm{ii}}-\mathrm{C} 5-\mathrm{C} 6$ & $117.9(7)$ \\
\hline $\mathrm{Cl} 2-\mathrm{Cu} 2-\mathrm{Cl}^{\mathrm{i}}$ & $90.87(7)$ & $\mathrm{C} 5-\mathrm{C} 6-\mathrm{C} 7$ & $115.4(6)$ \\
\hline $\mathrm{Cl} 2-\mathrm{Cu} 2-\mathrm{O} 1 \mathrm{~W}^{\mathrm{i}}$ & $90.51(19)$ & $\mathrm{C} 6-\mathrm{C} 7-\mathrm{C} 8$ & $112.9(6)$ \\
\hline $\mathrm{Cl} 3-\mathrm{Cu} 2-\mathrm{O} 1 \mathrm{~W}$ & $91.17(15)$ & $\mathrm{N} 2-\mathrm{C} 8-\mathrm{C} 7$ & $111.8(7)$ \\
\hline $\mathrm{Cl} 2-\mathrm{Cu} 2-\mathrm{Cl} 3$ & $90.87(7)$ & $\mathrm{C} 1-\mathrm{C} 2-\mathrm{H} 2 \mathrm{D}$ & 109.00 \\
\hline $\mathrm{Cl} 3-\mathrm{Cu} 2-\mathrm{Cl}^{\mathrm{i}}$ & 180.00 & $\mathrm{C} 1-\mathrm{C} 2-\mathrm{H} 2 \mathrm{E}$ & 109.00 \\
\hline $\mathrm{Cl} 3-\mathrm{Cu} 2-\mathrm{O} 1 \mathrm{~W}^{\mathrm{i}}$ & $88.83(15)$ & $\mathrm{H} 2 \mathrm{D}-\mathrm{C} 2-\mathrm{H} 2 \mathrm{E}$ & 108.00 \\
\hline $\mathrm{Cl} 2-\mathrm{Cu} 2-\mathrm{O} 1 \mathrm{~W}$ & $90.51(19)$ & $\mathrm{C} 3-\mathrm{C} 2-\mathrm{H} 2 \mathrm{E}$ & 109.00 \\
\hline 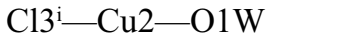 & $88.83(15)$ & $\mathrm{C} 3-\mathrm{C} 2-\mathrm{H} 2 \mathrm{D}$ & 109.00 \\
\hline $\mathrm{O} 1 \mathrm{~W}-\mathrm{Cu} 2-\mathrm{O} 1 \mathrm{~W}^{\mathrm{i}}$ & 180.00 & $\mathrm{C} 4-\mathrm{C} 3-\mathrm{H} 3 \mathrm{~A}$ & 109.00 \\
\hline $\mathrm{Cl} 2^{\mathrm{i}}-\mathrm{Cu} 2-\mathrm{Cl}^{\mathrm{i}}$ & $89.13(7)$ & $\mathrm{C} 2-\mathrm{C} 3-\mathrm{H} 3 \mathrm{~B}$ & 109.00 \\
\hline $\mathrm{Cl} 2-\mathrm{Cu} 2-\mathrm{O} 1 \mathrm{~W}^{\mathrm{i}}$ & $89.49(19)$ & $\mathrm{C} 2-\mathrm{C} 3-\mathrm{H} 3 \mathrm{~A}$ & 109.00 \\
\hline $\mathrm{Cl}^{\mathrm{i}}-\mathrm{Cu} 2-\mathrm{O} 1 \mathrm{~W}^{\mathrm{i}}$ & $91.17(15)$ & $\mathrm{C} 4-\mathrm{C} 3-\mathrm{H} 3 \mathrm{~B}$ & 109.00 \\
\hline $\mathrm{Cu} 1-\mathrm{Cl} 3-\mathrm{Cu} 2$ & $113.22(6)$ & $\mathrm{H} 3 \mathrm{~A}-\mathrm{C} 3-\mathrm{H} 3 \mathrm{~B}$ & 108.00 \\
\hline $\mathrm{O} 5-\mathrm{Cl} 1-\mathrm{O} 8$ & $108.9(3)$ & $\mathrm{H} 4 \mathrm{~A}-\mathrm{C} 4-\mathrm{H} 4 \mathrm{~B}$ & 108.00 \\
\hline $\mathrm{O} 6-\mathrm{Cl1}-\mathrm{O} 7$ & $109.4(3)$ & $\mathrm{N} 1-\mathrm{C} 4-\mathrm{H} 4 \mathrm{~A}$ & 110.00 \\
\hline $\mathrm{O} 6-\mathrm{Cl1}-\mathrm{O} 8$ & $110.2(3)$ & $\mathrm{N} 1-\mathrm{C} 4-\mathrm{H} 4 \mathrm{~B}$ & 110.00 \\
\hline $\mathrm{O} 7-\mathrm{Cl1}-\mathrm{O} 8$ & $109.1(3)$ & $\mathrm{C} 3-\mathrm{C} 4-\mathrm{H} 4 \mathrm{~A}$ & 109.00 \\
\hline $\mathrm{O} 5-\mathrm{Cl1}-\mathrm{O} 6$ & $111.2(3)$ & $\mathrm{C} 3-\mathrm{C} 4-\mathrm{H} 4 \mathrm{~B}$ & 110.00 \\
\hline $\mathrm{O} 5-\mathrm{Cl1}-\mathrm{O} 7$ & $108.0(3)$ & $\mathrm{C} 5-\mathrm{C} 6-\mathrm{H} 6 \mathrm{~B}$ & 108.00 \\
\hline $\mathrm{Cu} 1-\mathrm{O} 1-\mathrm{C} 1$ & $124.4(5)$ & $\mathrm{C} 7-\mathrm{C} 6-\mathrm{H} 6 \mathrm{~A}$ & 108.00 \\
\hline $\mathrm{Cu} 1-\mathrm{O} 2-\mathrm{C}^{\mathrm{ii}}$ & $122.7(5)$ & $\mathrm{C} 5-\mathrm{C} 6-\mathrm{H} 6 \mathrm{~A}$ & 108.00 \\
\hline $\mathrm{Cu} 1-\mathrm{O} 3-\mathrm{C} 5$ & $125.7(5)$ & $\mathrm{H} 6 \mathrm{~A}-\mathrm{C} 6-\mathrm{H} 6 \mathrm{~B}$ & 107.00 \\
\hline $\mathrm{Cu} 1-\mathrm{O} 4-\mathrm{C} 5^{\mathrm{ii}}$ & $120.6(6)$ & $\mathrm{C} 7-\mathrm{C} 6-\mathrm{H} 6 \mathrm{~B}$ & 108.00 \\
\hline $\mathrm{H} 1 \mathrm{WA}-\mathrm{O} 1 \mathrm{~W}-\mathrm{H} 1 \mathrm{WB}$ & 104.00 & $\mathrm{C} 8-\mathrm{C} 7-\mathrm{H} 7 \mathrm{~A}$ & 109.00 \\
\hline $\mathrm{Cu} 2-\mathrm{O} 1 \mathrm{~W}-\mathrm{H} 1 \mathrm{WB}$ & 124.00 & $\mathrm{C} 6-\mathrm{C} 7-\mathrm{H} 7 \mathrm{~B}$ & 109.00 \\
\hline $\mathrm{Cu} 2-\mathrm{O} 1 \mathrm{~W}-\mathrm{H} 1 \mathrm{WA}$ & 133.00 & $\mathrm{C} 6-\mathrm{C} 7-\mathrm{H} 7 \mathrm{~A}$ & 109.00 \\
\hline $\mathrm{H} 1 \mathrm{~A}-\mathrm{N} 1-\mathrm{H} 1 \mathrm{~B}$ & 109.00 & $\mathrm{C} 8-\mathrm{C} 7-\mathrm{H} 7 \mathrm{~B}$ & 109.00 \\
\hline $\mathrm{C} 4-\mathrm{N} 1-\mathrm{H} 1 \mathrm{~A}$ & 109.00 & $\mathrm{H} 7 \mathrm{~A}-\mathrm{C} 7-\mathrm{H} 7 \mathrm{~B}$ & 108.00 \\
\hline $\mathrm{C} 4-\mathrm{N} 1-\mathrm{H} 1 \mathrm{C}$ & 109.00 & $\mathrm{H} 8 \mathrm{~A}-\mathrm{C} 8-\mathrm{H} 8 \mathrm{~B}$ & 108.00 \\
\hline $\mathrm{H} 1 \mathrm{~B}-\mathrm{N} 1-\mathrm{H} 1 \mathrm{C}$ & 109.00 & $\mathrm{~N} 2-\mathrm{C} 8-\mathrm{H} 8 \mathrm{~A}$ & 109.00 \\
\hline $\mathrm{H} 1 \mathrm{~A}-\mathrm{N} 1-\mathrm{H} 1 \mathrm{C}$ & 110.00 & $\mathrm{~N} 2-\mathrm{C} 8-\mathrm{H} 8 \mathrm{~B}$ & 109.00 \\
\hline $\mathrm{C} 4-\mathrm{N} 1-\mathrm{H} 1 \mathrm{~B}$ & 109.00 & $\mathrm{C} 7-\mathrm{C} 8-\mathrm{H} 8 \mathrm{~A}$ & 109.00 \\
\hline $\mathrm{H} 2 \mathrm{~A}-\mathrm{N} 2-\mathrm{H} 2 \mathrm{C}$ & 110.00 & $\mathrm{C} 7-\mathrm{C} 8-\mathrm{H} 8 \mathrm{~B}$ & 109.00 \\
\hline $\mathrm{H} 2 \mathrm{~A}-\mathrm{N} 2-\mathrm{H} 2 \mathrm{~B}$ & 109.00 & & \\
\hline $\mathrm{O} 1-\mathrm{Cu} 1-\mathrm{Cl} 3-\mathrm{Cu} 2$ & $-131.91(18)$ & $\mathrm{Cl} 2-\mathrm{Cu} 2-\mathrm{Cl} 3-\mathrm{Cu} 1$ & $81.65(9)$ \\
\hline $\mathrm{O} 2-\mathrm{Cu} 1-\mathrm{Cl} 3-\mathrm{Cu} 2$ & $46.8(2)$ & $\mathrm{O} 1 \mathrm{~W}^{\mathrm{i}}-\mathrm{Cu} 2-\mathrm{Cl} 3-\mathrm{Cu} 1$ & $171.1(2)$ \\
\hline $\mathrm{O} 3-\mathrm{Cu} 1-\mathrm{Cl} 3-\mathrm{Cu} 2$ & $137.66(17)$ & $\mathrm{Cu} 1-\mathrm{O} 1-\mathrm{C} 1-\mathrm{C} 2$ & $174.1(5)$ \\
\hline $\mathrm{O} 4-\mathrm{Cu} 1-\mathrm{Cl} 3-\mathrm{Cu} 2$ & $-42.78(18)$ & $\mathrm{Cu} 1-\mathrm{O} 1-\mathrm{C} 1-\mathrm{O} 2^{\mathrm{ii}}$ & $-3.6(11)$ \\
\hline $\mathrm{Cl} 3-\mathrm{Cu} 1-\mathrm{O} 1-\mathrm{C} 1$ & $-170.4(6)$ & $\mathrm{Cu} 1-\mathrm{O} 2-\mathrm{C} 1^{\mathrm{ii}}-\mathrm{O} 1^{\mathrm{ii}}$ & $0.0(12)$ \\
\hline
\end{tabular}




$\begin{array}{llll}\mathrm{O} 3-\mathrm{Cu} 1-\mathrm{O} 1-\mathrm{C} 1 & -78.0(6) & \mathrm{Cu} 1-\mathrm{O} 2-\mathrm{C} 1^{\mathrm{ii}}-\mathrm{C}^{2 i} & 177.6(5) \\ \mathrm{O} 4-\mathrm{Cu} 1-\mathrm{O} 1-\mathrm{C} 1 & 90.3(6) & \mathrm{Cu} 1-\mathrm{O} 3-\mathrm{C} 5-\mathrm{C} 6 & -178.5(5) \\ \mathrm{C} 13-\mathrm{Cu} 1-\mathrm{O} 2-\mathrm{C} 1^{\mathrm{ii}} & 172.2(6) & \mathrm{Cu} 1-\mathrm{O} 3-\mathrm{C} 5-\mathrm{O} 4^{\mathrm{ii}} & 2.9(11) \\ \mathrm{O} 3-\mathrm{Cu} 1-\mathrm{O} 2-\mathrm{C} 1^{\mathrm{ii}} & 79.8(6) & \mathrm{Cu} 1-\mathrm{O} 4-\mathrm{C} 5^{\mathrm{ii}}-\mathrm{O}^{\mathrm{ii}} & 2.5(11) \\ \mathrm{O} 4-\mathrm{Cu} 1-\mathrm{O} 2-\mathrm{C} 1^{\mathrm{ii}} & -88.6(6) & \mathrm{Cu} 1-\mathrm{O} 4-\mathrm{C} 5^{\mathrm{ii}}-\mathrm{C} 6^{\mathrm{ii}} & -178.9(5) \\ \mathrm{C} 13-\mathrm{Cu} 1-\mathrm{O} 3-\mathrm{C} 5 & 175.4(6) & \mathrm{O} 1-\mathrm{C} 1-\mathrm{C} 2-\mathrm{C} 3 & 173.9(7) \\ \mathrm{O} 1-\mathrm{Cu} 1-\mathrm{O} 3-\mathrm{C} 5 & 81.8(6) & \mathrm{O} 22^{\mathrm{ii}}-\mathrm{C} 1-\mathrm{C} 2-\mathrm{C} 3 & -8.3(11) \\ \mathrm{O} 2-\mathrm{Cu} 1-\mathrm{O} 3-\mathrm{C} 5 & -85.9(6) & \mathrm{C} 1-\mathrm{C} 2-\mathrm{C} 3-\mathrm{C} 4 & -179.9(7) \\ \mathrm{C} 13-\mathrm{Cu} 1-\mathrm{O} 4-\mathrm{C} 5^{\mathrm{ii}} & -177.9(5) & \mathrm{C} 2-\mathrm{C} 3-\mathrm{C} 4-\mathrm{N} 1 & -68.8(9) \\ \mathrm{O} 1-\mathrm{Cu} 1-\mathrm{O} 4-\mathrm{C} 5^{\mathrm{ii}} & -84.5(6) & \mathrm{O} 3-\mathrm{C} 5-\mathrm{C} 6-\mathrm{C} 7 & 170.5(7) \\ \mathrm{O} 2-\mathrm{Cu} 1-\mathrm{O} 4-\mathrm{C} 5^{\mathrm{ii}} & 83.7(6) & \mathrm{O} 4{ }^{\mathrm{ii}}-\mathrm{C} 5-\mathrm{C} 6-\mathrm{C} 7 & -10.7(10) \\ \mathrm{C} 2-\mathrm{Cu} 2-\mathrm{Cl} 3-\mathrm{Cu} 1 & -98.35(9) & \mathrm{C} 5-\mathrm{C} 6-\mathrm{C} 7-\mathrm{C} 8 & -167.0(7) \\ \mathrm{O} 1 \mathrm{2}-\mathrm{Cu} 2-\mathrm{Cl}-\mathrm{Cu} 1 & -8.9(2) & \mathrm{C} 6-\mathrm{C} 7-\mathrm{C} 8-\mathrm{N} 2 & 63.8(8)\end{array}$

Symmetry codes: (i) $-x+2,-y+2,-z$; (ii) $-x+2,-y+2,-z+1$; (iii) $x,-y+3 / 2, z-1 / 2$; (iv) $-x+2, y-1 / 2,-z+1 / 2$; (v) $-x+2, y+1 / 2,-z+1 / 2$; (vi) $-x+1, y+1 / 2$, $-z+1 / 2$; (vii) $-x+2,-y+1,-z+2$; (viii) $-x+1,-y+1,-z+2$; (ix) $x-1, y, z$; (x) $-x+1,-y+1,-z+1$; (xi) $-x+1, y-1 / 2,-z+1 / 2$; (xii) $x,-y+3 / 2, z+1 / 2$; (xiii) $-x+2$, $y-1 / 2,-z+3 / 2$; (xiv) $x-1,-y+3 / 2, z-1 / 2$; (xv) $x+1, y, z$; (xvi) $-x+2, y+1 / 2,-z+3 / 2$; (xvii) $x+1,-y+3 / 2, z+1 / 2$.

Hydrogen-bond geometry $\left(A,{ }^{\circ}\right)$

\begin{tabular}{lllll}
\hline$D-\mathrm{H} \cdots A$ & $D-\mathrm{H}$ & $\mathrm{H} \cdots A$ & $D \cdots A$ & $D-\mathrm{H} \cdots A$ \\
\hline $\mathrm{O} 1 W-\mathrm{H} 1 W A \cdots \mathrm{O} 2$ & 1.0000 & 2.2500 & $3.046(9)$ & 135.00 \\
$\mathrm{O} 1 W-\mathrm{H} 1 W A \cdots \mathrm{O} 4$ & 1.0000 & 2.5000 & $3.234(7)$ & 130.00 \\
$\mathrm{~N} 1-\mathrm{H} 1 A \cdots \mathrm{Cl} 2^{\mathrm{iv}}$ & 0.9100 & 2.3200 & $3.214(6)$ & 166.00 \\
$\mathrm{~N} 1-\mathrm{H} 1 B \cdots \mathrm{O} 1^{\mathrm{xii}}$ & 0.9100 & 2.1800 & $3.075(9)$ & 169.00 \\
$\mathrm{~N} 1-\mathrm{H} 1 B \cdots \mathrm{O} 4^{\mathrm{xii}}$ & 0.9100 & 2.4500 & $2.989(9)$ & 118.00 \\
$\mathrm{~N} 1-\mathrm{H} 1 C \cdots \mathrm{O}^{\mathrm{xv}}$ & 0.9100 & 2.5900 & $3.015(9)$ & 109.00 \\
$\mathrm{~N} 1-\mathrm{H} 1 C \cdots 5^{\mathrm{vii}}$ & 0.9100 & 2.2600 & $3.074(8)$ & 148.00 \\
$\mathrm{O} 1 W-\mathrm{H} 1 W B \cdots \mathrm{O} 1^{\mathrm{v}}$ & 0.9900 & 2.3500 & $3.252(7)$ & 151.00 \\
$\mathrm{~N} 2-\mathrm{H} 2 A \cdots \mathrm{O} 6^{\mathrm{x}}$ & 0.9100 & 2.5000 & $3.146(8)$ & 128.00 \\
$\mathrm{~N} 2-\mathrm{H} 2 A \cdots \mathrm{Cl} 2^{\mathrm{xii}}$ & 0.9100 & 2.4900 & $3.245(6)$ & 140.00 \\
$\mathrm{~N} 2-\mathrm{H} 2 B \cdots \mathrm{O} 7$ & 0.9100 & 2.1100 & $2.956(8)$ & 154.00 \\
$\mathrm{~N} 2-\mathrm{H} 2 C \cdots \mathrm{Cl} 3^{\mathrm{xii}}$ & 0.9100 & 2.4600 & $3.316(7)$ & 157.00 \\
$\mathrm{~N} 2-\mathrm{H} 2 C \cdots \mathrm{O} 3^{\mathrm{xii}}$ & 0.9100 & 2.5000 & $3.075(7)$ & 122.00 \\
$\mathrm{C} 2-\mathrm{H} 2 D \cdots \mathrm{Cl} 2^{\mathrm{iv}}$ & 0.9900 & 2.8200 & $3.708(7)$ & 149.00 \\
$\mathrm{C} 2-\mathrm{H} 2 D \cdots \mathrm{Cl} 3^{\mathrm{xii}}$ & 0.9900 & 2.8000 & $3.511(8)$ & 129.00 \\
$\mathrm{C} 4-\mathrm{H} 4 A \cdots \mathrm{O} 5^{\mathrm{xv}}$ & 0.9900 & 2.5800 & $3.215(9)$ & 122.00 \\
$\mathrm{C} 6-\mathrm{H} 6 A \cdots \mathrm{N} 2$ & 0.9900 & 2.6100 & $3.031(9)$ & 106.00 \\
$\mathrm{C} 8-\mathrm{H} 8 B \cdots \mathrm{O} 8^{\mathrm{x}}$ & 0.9900 & 2.5100 & $3.294(9)$ & 136.00 \\
\hline
\end{tabular}

Symmetry codes: (iv) $-x+2, y-1 / 2,-z+1 / 2$; (v) $-x+2, y+1 / 2,-z+1 / 2$; (vii) $-x+2,-y+1,-z+2$; (x) $-x+1,-y+1,-z+1 ;(x i i) x,-y+3 / 2, z+1 / 2$; (xv) $x+1, y, z$. 